\title{
Does Poor Mean Cheap? A Comparative Look at Africa's Industrial Labor Costs
}

\section{Alan Gelb, Christian Meyer, and Vijaya Ramachandran}

\begin{abstract}
Africa's industrial progress has been disappointing. With the exception of South African auto components and garments, both of which have benefited from special incentives, Africa exports almost no manufactures that are not based on the processing of raw materials. Despite considerable rhetoric on the need to develop manufacturing as well as support by donors, what limited progress has been made has often been uneven and isolated. Much of Africa's manufacturing sector is still characterized by a significant economic dualism between a large number of small-scale enterprises in the informal sector and a handful of more efficient large-scale operations in the formal sector.
\end{abstract}

Following on from previous research on "external costs," this paper compares labor costs and productivity in selected African countries relative to comparators using data for 25 countries from the World Bank's Enterprise Surveys. We conclude that industrial labor costs are far higher in Africa than one might expect, given levels of Gross Domestic Product (GDP) per capita. Part of this is an "enclave effect": both labor costs and labor productivity are far higher in Africa, relative to GDP per capita, than in comparator countries. Another part reflects a steeper labor cost curve; as firms are larger and more productive their labor costs increase more in Africa than elsewhere. But there is still a sizeable residual "Africa effect" after controlling for such factors. We cannot test rigorously for the reasons behind these results but consider some plausible explanations. We also consider how Africa's distinctive pattern, in terms of purchasing power parity exchange rates could affect the results.

We conclude with some implications for policy. Certainly there is an urgent need to reduce "external costs," through focused investments (power) as well as a general improvement in the business climate. However, with the exception of a few countries like Ethiopia, it is not clear that Africa's low-income level automatically translates into a comparative advantage in low-wage basic manufactures. We argue that it is more likely to reside in sectors closely linked with the rich and varied natural resource endowments of the countries, whether supplying or processing industries.

JEL Codes: D2, L6, O14

Keywords: Africa, manufacturing, private sector, labor cost, productivity, firm survey. 


\title{
Does Poor Mean Cheap? A Comparative Look at Africa's Industrial
} Labor Costs

\author{
Alan Gelb \\ Center for Global Development \\ Christian Meyer \\ Center for Global Development \\ Vijaya Ramachandran \\ Center for Global Development
}

E-mail addresses: agelb@cgdev.org, cmeyer@cgdev.org, vramachandran@ cgdev.org. We are grateful to Michael Clemens, Kimberly Ann Elliott, Alvaro Gonzalez, Leonardo Iacovone, Michael Klein, Todd Moss, Mead Over, Jan Rieländer, David Roodman, Arvind Subramanian, Gaiv Tata, Franck Wiebe, Andrew Zeitlin, an anonymous peer reviewer, and seminar participants at the Center for Global Development, Duke University, the IMF Africa Macro Network, Oxford University CSAE Conference 2013, and the Africa Private Sector and Finance Unit of the World Bank for comments and suggestions. The authors remain solely responsible for any errors.

CGD is grateful for contributions from the William and Flora Hewlett Foundation and the Danish Ministry of Foreign Affairs in support of this work.

Alan Gelb, Christian Meyer, and Vijaya Ramachandran. 2013. "Does Poor Mean Cheap? A Comparative Look at Africa’s Industrial Labor Costs.” CGD Working Paper 325.

Washington, DC: Center for Global Development.

http://www.cgdev.org/publication/does-poor-mean-cheap

Center for Global Development 1800 Massachusetts Ave., NW Washington, DC 20036

202.416 .4000

(f) 202.416 .4050

www.cgdev.org
The Center for Global Development is an independent, nonprofit policy research organization dedicated to reducing global poverty and inequality and to making globalization work for the poor. Use and dissemination of this Working Paper is encouraged; however, reproduced copies may not be used for commercial purposes. Further usage is permitted under the terms of the Creative Commons License.

The views expressed in CGD Working Papers are those of the authors and should not be attributed to the board of directors or funders of the Center for Global Development. 


\section{Motivation and Literature}

Africa's manufacturing industry, although often eclipsed by the existence of rich natural resources, is sometimes seen as a potentially competitive sector that could capitalize on the continent's abundant supply of unskilled, low-cost labor (Dinh et al., 2012). Recently, reports of rising wages in China and other established Asian manufacturing hubs have led to a renewed focus on Africa as a destination for global companies in their continued pursuit of cheap labor. Based on a labor cost advantage, it is argued that African countries can attract foreign direct investment (FDI) and, through linkages and spillover effects, spearhead economic diversification away from primary commodities.

In these efforts, the manufacturing sector has been the target of countless state-led interventions to promote industrial development and induce broad-based structural change (Tybout, 2000). Many such interventions have been supported and funded by development partners and continue to be so. While official development assistance (ODA) flows to support the industrial sector represented only 10.5 percent of total production sector-allocable ODA to Sub-Saharan Africa in 2010, these figures likely understate how frequently and widely international development partners recommend the promotion of manufacturing industries in a wide variety of projects, including export zones and growth poles (Dinh et al., 2012; World Bank, 2012a).

Progress, however, has been disappointing. The share of manufacturing in economic output and in employment has been decreasing or stagnant in most countries. On paper, about 20 percent of Africa's exports are industrial products. However, with the exception of South African auto components and garments, both of which have benefited from special incentives, including AGOA for the latter, Africa exports almost no manufactures that are not based on the processing of raw materials (Gelb, 2012). In a detailed study of bilateral aid flows, Rotunno et al. (2012) find that about half of AGOA exports are essentially re-packaged products from China. The United Nations Economic Commission for Africa (UNECA) described the results of the industrialization and diversification process as reflecting "volatility and fragility" and summarized that "Africa has been unable to sustain a strong foundation of diversified economy", citing ill-advised industrial policy, poor infrastructure, high sovereign risk, and rigid macroeconomic frameworks as barriers (UNECA, 2007). Previous research stressed the role of high "external costs" for African firms, including those due to unreliable power supply, costly logistics and bribes and corruption (Eifert et al., 2008). Together with the small market size of most African economies and high uncertainty, these have undoubtedly been factors inhibiting the emergence of 
competitive manufacturing industry.

This paper focuses on the role of factor prices for the development of Africa's manufacturing industry. We specifically explore the cost of industrial labor, relative to the cost faced by industry in comparator and likely competitor countries. Anecdotal evidence, as well as data collected through firm-level surveys, suggests that African industrial labor costs may be higher than expected relative to global comparators (World Bank 2009a, 2009b, 2011).

We do not aim to answer the question of whether Africas perceived shortfalls in industrial competitiveness can be causally attributed to costly industrial labor, low productivity, or a combination both ${ }^{1}$. We do, however, hope to answer the question of whether prevailing industrial labor costs across Sub-Saharan Africa are consistent with a vision of establishing Africa as the next low-cost manufacturing destination. While relevant from the perspective of domestic and international investors, we mainly hope to contribute to the debate about job creation in low-income economies and particularly Africa, which we perceive as a significant challenge for development policy over the next years. Given the age structure of the population in most African countries, national governments and international partners continue to push for economic transformation and job creation (African Development Bank et al., 2013). Many policymakers and donors hope that Africa can capture a share of the global manufacturing jobs that have migrated from developed into developing countries and from Northeast Asia to East and South Asia (World Bank, 2012b). Labor cost is a key determinant of the location of labor-intensive, light manufacturing industries that could absorb the continents increasing labor supply, and is consequently the focus of our analysis.

This paper is closely related to an exhaustive firm-level study for Ghana conducted by Söderbom and Teal (2004). They argue that larger or higher-productivity firms in Africa face higher labor costs than would be expected on the basis of an efficient labor market, relative to smaller or less productive ones (henceforth: ST effect). This effect could be more significant for Africa then elsewhere, for several reasons. Higher-productivity labor is typically more skilled and the premium on skills could be higher in Africa than elsewhere. It could also be because there are so few large and highly productive firms in Africa's small economies, and that this makes them more visible and subject to government regulators or organized labor seeking to appropriate a share of productivity rents that would otherwise

\footnotetext{
${ }^{1}$ We thank an anonymous reviewer for highlighting this point.
} 
go to capital. In this scenario, Africa's potential competitiveness is choked off by rising labor costs in any "islands of productivity".

The rest of the paper is organized as follows. Section 2 describes the empirical approach, including key questions and hypotheses. Section 3 describes the data and descriptive statistics while Section 4 discusses the empirical results. Section 5 presents robustness checks and interpretations of the results and Section 6 concludes.

\section{Empirical Approach}

Using firm-level survey data from the World Bank Enterprise Survey, we estimate a series of ordinary least squares (OLS) regressions for labor costs, moving progressively from the simplest formulations to more complex versions that include interaction terms between Africa, firm-level characteristics, and structural characteristics of the labor market.

In an approach that is similar to ST (2004), we first estimate a Mincer-inspired wage function at the firm-level, exploiting data on the average educational attainment of production workers and controlling for various firm characteristics. Educational attainment data is unfortunately only available for a small sub-set of Enterprise Survey rounds. We subsequently move to a broader specification in which we proxy unobserved labor quality by firm-level productivity, controlling for firm characteristics and structural macroeconomic determinants.

\subsection{Questions and Hypotheses}

We consider the following questions: Africa may be poor, but given that the level of gross domestic product (GDP) per capita is so low, is its industrial labor also cheap? Is it cheap in a nominal sense relative to comparators, or in efficiency-adjusted terms? If it is not cheap, is industrial productivity sufficiently high to make it competitive?

Managers of firms, whether domestic or international, will likely care about three different cost and productivity metrics when making their investment decisions. First, the total cost associated with a given level of labor input. Second, the output associated with a level of labor input. Third, the cost of labor associated with a unit of output. Following this logic, this paper tries to disentangle the question of labor competitiveness for African manufacturing firms by analyzing in a comparative, cross-sectional framework, costs and metrics that relate labor costs to productivity.

We relate these metrics to GDP per capita in order to better understand the role of labor 
costs in Africas structural transformation. It is natural to assume that industrial labor in Sub-Saharan Africa, still the poorest region in the world in terms of average economic output and the percentage of people living below $\$ 1.25$ a day, is substantially less costly but also less productive.

The first hypothesis is that poor means cheap. A lower national income per capita is associated with lower labor cost, controlling for firm characteristics. A second hypothesis is that poor also means less productive: lower national income per capita is associated with lower productivity per worker, controlling for firm characteristics. A third question concerns unit labor costs: manufacturing firms in Africa should exhibit productivityto-cost ratios that are similar to comparable manufacturing firms in other developing countries. We also consider possible differences within the industrial sector, for example, whether labor is relatively more or less costly in Africa in more productive or more capitalintensive firms.

The null hypothesis is therefore that the relationship between pay and productivity, or pay and size (employment) is identical for African and non-African firms.

To better understand these patterns, we consider cross-country differences in the price level. If African labor is not cheap or as cheap as one might expect given levels of GDP per capita this could mean that real wages are high relative to those in comparator countries or that living costs are high. Countries that have high (costly) purchasing power parity (PPP) exchange rates relative to their income or productivity levels will have a harder time competing with low-cost countries in competitive manufacturing industries. Rodrik (2008) provides evidence that real exchange rate undervaluation helps economic growth and increases the profitability of the tradable sector. The reason may reflect exchange rate policy or exogenous flows such as aid or remittances. But it may also result from other factors, such as productivity differentials in sectors with high transport costs (including agriculture) or geography: a sparse country may be unable to exploit conglomeration externalities. Price-level divergence causes real wages to diverge from nominal wages; it also complicates the comparative measurement of productivity differences if a substantial portion of output is sold at home. 


\subsection{Data and Descriptive Statistics}

Using a selected sample of countries from the World Bank's Enterprise Surveys ${ }^{2}$, we examine the hypotheses described above. Our sample includes comparable, cross-sectional data from 10,502 manufacturing firms in 12 Sub-Saharan African countries (Angola, Ethiopia, Ghana, Kenya, Mali, Mozambique, Nigeria, Senegal, South Africa, Tanzania, Uganda, Zambia) and 13 comparators from four regions (Indonesia, Philippines, Vietnam, Russia, Turkey, Ukraine, Argentina, Brazil, Chile, Colombia, Mexico, Uruguay, and Bangladesh). To maximize the data availability, we focus on surveys conducted around 2006/2007.

The data covers formal firms that are classified with ISIC codes 15-37, 45, 50-52, 55, 6064 , and 72. Interviewers conduct face-to-face interviews using standardized questionnaires for the manufacturing and the service sector. Topics covered include information on firm characteristics, the business environment, access to finance, annual sales, costs of inputs and labor, workforce composition, and basic performance measures. Sample data is then stratified using random sampling with replacement along strata for firm size, business sector, and geographic region. For the purpose of this paper, we do not use the sampling weights provided because we find that the limited availability of the data required for our analyses would change the sample composition, and because we do not aspire to extrapolate our findings for single groups of companies to the national level. ${ }^{3}$ We look at the sample as telling us something about firms of certain types rather than derive nationally representative averages.

We exclude firms that are not classified as manufacturing according to the ISIC industry classification. We follow the World Bank's methodology in defining manufacturing as ISIC 15 to 37. In the case of Ethiopia, we manually match the available ISIC 4-digit classes into ISIC 2-digit divisions, and exclude firms in which the government holds at least 50 percent of shares. Finally, we drop observations with missing or negative values for sales and cost.

To allow for the possibilities of transient fluctuations in the real exchange rates of the various countries against the US Dollar, we compared two methods of converting data into 2005 US dollars. The first converted local currency values in the year of the survey into US dollars at the current exchange rate and then deflated these to 2005 values using the US deflator. The second used local price indices to deflate values to 2005 levels and then

\footnotetext{
${ }^{2}$ Since 2002, the World Bank has conducted firm surveys in 137 countries, 86 of which follow a globally standardized methodology. See www.enterprisesurveys.org/Methodology for more information.

${ }^{3}$ To some extent the weighting issue is addressed by including firm characteristics in regressions.
} 
converted these using 2005 exchange rates. Perhaps because the survey years were not too far from 2005 the results from these approaches were very close, with the correlation between them close to 1 . We therefore used the first method rather than an average.

Finally, we restrict our analysis to a cross-section of Sub-Saharan African economies with at least 200 firms in the raw data set: Angola, Ethiopia, Ghana, Kenya, Mali, Mozambique, Nigeria, Senegal, South Africa, Tanzania, Uganda, and Zambia. In 2010, these countries accounted for 74 percent of the region's economic output, 61 percent of population, and 70 percent of merchandise exports. ${ }^{4}$

One reason for excluding small samples is the problem of how to deal with outliers. Close examination of the data shows a number of firms where data values or ratios are highly implausible, and far enough from realistic values as to threaten to affect statistical results - even with robust regressions. For purposes of this analysis, we tested three different methods of correcting for outliers in the sales and cost data. This involves a difficult tradeoff, especially at the high end, where it is difficult to separate outlier errors from the few high-productivity firms in the sample for a particular country. This problem is compounded in small samples. Our preferred approach is to log-normalize all input variables and the ratios of labor cost per worker, sales per worker, and material cost per worker, and then drop all observations that are more than three standard deviations away from the geometric mean of the transformed values in each country and each year. This produces samples with reasonably regular features, including ratios of means to medians. ${ }^{5}$ The downside is that this selection process may obscure some of the dualism within the industrial sector by taking out some very large or genuinely productive firms. Alternatively, we trim the top and bottom one and five percent of all input variables for every country and year. However, trimming the top and bottom of all input variables did not prove conservative enough for our data, as some unlikely firms remain. In our preferred method, we drop 980 out of 11,482 observations in the overall data set, or a total of about 8.5 percent.

For the comparator countries used in the sample, we sought out a set of countries with similar survey data that constitute a reasonable set of actual or potential competitors for

\footnotetext{
${ }^{4}$ Based on World Bank World Development Indicators (WDI) and United Nations Conference on Trade and Development (UNCTAD) data.

${ }^{5}$ We also tried Winsorising and trimming the data.
} 
African firms, whether in low or middle-income countries. ${ }^{6}$ Low-income comparators in our sample include Bangladesh, Vietnam, and Indonesia. Middle-income countries include Turkey and Brazil. We were not able to include China and India in this exercise due to lack of comparable survey instruments, but we include some summary statistics on India below. As before, we strove to select countries with larger sample sizes. Except for Ukraine and Uruguay (which have slightly fewer firms), all our comparators have samples with more than 200 firms in the raw data. Outliers were treated in the same way as for African countries.

At the medians, the African firms in our sample are smaller and younger than firms in our comparator countries. In the pooled sample, the median African firm has 13 employees and is 10 years old, while the median comparator firm has 33 employees and is 15 years old.

Table 1 shows that the African countries included in our sample are, on average, poorer than the comparator countries. Average GDP per capita in the surveyed year was about US $\$ 750$ in the African countries, compared to just over $\$ 4,000$ in our comparators. Manufacturing industry represents a much smaller share of GDP in Africa. The economies are quite open as measured by exports-to-GDP, which partly reflects their small size and the weight of commodity exports. African countries have a smaller share of manufactured exports but even this is misleading as most are processed primary products. Despite their relative land abundance, most African countries are net food importers, in sharp contrast to the comparator countries in Latin America and Asia. Senegal imports $\$ 66$ of food per capita per year, the highest in our sample.

Relative to their income, most African countries appear costly, as measured by their PPP price level of GDP. Ethiopia stands out as both very poor and cheap. Zambia's price level, in contrast, is as high as that of any country in the comparator group. Although dependency rates tend to be a little higher in Africa than in some of the other countries, labor force participation rates are high, except in South Africa, which has the lowest employment ratio in the sample. Overall, demographics and labor force participation rates are therefore not major factors that explain possible differences in the ratio of wages to GDP per capita.

\footnotetext{
${ }^{6}$ There is little point in including small, remote countries with little manufacturing capacity in the comparator set, as these are not significant actual or potential competitors for African manufacturers. The inclusion of a number of middle-income countries is motivated partly by the somewhat distinctive nature of South Africa within the Africa sample.
} 
Table 2 describes basic characteristics of our sample of firms. Overall, our sample includes 10,502 firms in 25 countries. About 40 percent of them are located in SubSaharan Africa (about 15 percent of these are in South Africa) while the remaining 60 percent are in four regions of the world: East Asia and Pacific, Europe and Central Asia, Latin America and South Asia. Average firm size in Sub-Saharan Africa is almost one third smaller than in the other regions. ${ }^{7}$

African firms are also mostly younger than firms in the comparator group, and less likely to export. In terms of industries, African firms in our sample seem to be more concentrated. Food processing, garments, furniture, and fabricated metal products are the top four industries and account for nearly three quarters of all firms in Sub-Saharan Africa. In our set of comparator countries, the top four industries are food processing, apparel, textiles, and chemicals, accounting for about 58 percent of all industries. Nevertheless, the Africa and non-Africa samples have a high degree of industry overlap.

Table 3 shows survey medians, which provide a foretaste of some of the conclusions from the firm-level analysis. The first striking pattern is the level of industrial labor costs and labor productivity in Africa, relative to income. With a GDP per capita of \$498 Kenya compares with Bangladesh, but its median industrial labor cost is almost four times as high and its labor productivity even higher. Ethiopia has comparable labor cost and productivity to Bangladesh, but with a far lower income level. Overall, excluding South Africa as a middle-income country, the average level of labor costs in the African sample is $\$ 1,231$, which is close to that of the four poorest comparator countries (Bangladesh, Indonesia, Philippines and Vietnam), even though these are considerably richer. South Africa is not the richest of the middle-income countries, but its median labor cost is the highest in the sample, by a considerable margin.

Figures 1 to 3 show these relationships graphically, together with the $20^{\text {th }}$ and $80^{\text {th }}$ percentiles of the distributions. Unit labor costs, as measured by the share of labor costs in value-added, are higher in Africa but only slightly. The difference widens when sales are used as the denominator. The ratio of value added to sales is higher in Africa, probably reflecting the less specialized nature of its industrial supply chains.

There are, of course, limits imposed by our dataset. One concern is that the standard Enterprise Survey instrument only targets formal (registered) firms, effectively censoring

\footnotetext{
${ }^{7}$ This is in line with the general view in the literature on firm size in developing countries. See Tybout (2000) for a general overview of manufacturing firm characteristics in developing countries; see van Bisebroeck (2005) for an Africa-specific discussion of firm size and productivity.
} 
our sample at a lower bound for value added and labor costs. Excluding informal firms induces a possible bias that arises from the self-selection of firms into the formal versus informal sector. In most countries the informal sector consists of very small firms. Especially in Southern Africa, informal firms tend to be "survivalist": small, and with little productivity overlap with the formal sector (Gelb et al., 2009). But this is not always the case; we have also observed the presence of some larger and more productive firms in the informal sector in Kenya. If self-selection into the formal sector leaves out a substantial share of industrial activity in the informal sector in Africa, this could bias the formal sector results towards larger, more productive, firms. However, the fact that average firm size is smaller in most African countries than in most comparators indicates that this is not a likely explanation of the observed difference.

A more serious issue is the absence of India and China - two relatively poor industrial powerhouses - in our dataset because both countries have non-standardized surveys. This is partly offset by the inclusion of three poor countries - Bangladesh, Vietnam and Indonesia - which have also been successful in establishing strongly competitive manufacturing industries in sectors similar to those where low-income African countries might seek to compete.

We can, however, compare India to the African countries in our sample using simple ratios. $^{8}$ India's GDP per capita is about 10 percent higher than that of Bangladesh, and its PPP price level is comparable. The firms in the India sample are smaller in terms of employment, though large relative to those in the African samples. The median Indian firm is more capital intensive than its counterpart in Bangladesh and its value added per head is much higher. Its median labor costs are 55 percent higher than the median in Bangladesh but still below the median for all African countries except Ethiopia and Ghana. This may imply a somewhat more enclave-like industrial sector in India than in Bangladesh, though the difference pales next to the African cases. Kenya, for example, with lower GDP per capita has median labor cost and value added worker each around three times the Indian level.

We do not include Madagascar and Mauritius, two countries that have been relatively successful in the apparel sector, due to the small size of their samples, but the rationale

\footnotetext{
${ }^{8}$ Given the non-standardized survey instrument we do not apply the same outlier correction method in our analysis of India's Enterprise Survey. As a consequence, we only report median cost and productivity indicators which will be less affected by extreme values, whether at the top or the bottom of the distribution.
} 
for considering Mauritius as African rather than Asian is not clear, apart from convention.

We are also unable to control for intra-sectoral variations across countries. For example, there may be unobservable differences in the quality of equipment or certain features of the technology used in a particular sector for firms in Bangladesh vs. Mexico, that are not reflected in the book value of capital or other available measures. However, given that the entire sample of firms is drawn from traditional sectors that use fairly standardized technology, we are not overly concerned about this problem. We believe that the use of several controls in the econometric estimations, including industry and size dummies, yields categories that are reasonably homogeneous.

A final limitation of the data is that it is a simple cross-section so that it is not possible to infer causality from estimated relationships. From the firm perspective, it is more natural to take labor costs as exogenous and decisions regarding industry, size, technology and productivity as endogenous than to seek to "explain" labor costs on the basis of such variables. To some degree the use of industry and size dummies helps to contain this problem, but it is still the case that the mix of firms and productivity seen in the individual countries reflects, among other things, other factors that influence the level of labor costs.

\section{Econometric Results}

We now turn to some simple econometric tests of our hypotheses about firms' factor prices relative to level of development, controlling for firm characteristics such as size, age and ownership.

We hypothesize that labor cost depends on an observed level of human capital such as educational attainment and unobserved differences at the firm level. We begin by asking whether we can we get a better understanding of human capital, even without employee-level data. Some Enterprise Survey rounds include standardized questions about the average educational attainment of typical production workers. We construct a small sub-sample of countries with such data. In Africa, we have data for Ghana, Mozambique, Senegal, Zambia; the comparators are Brazil, Indonesia, Philippines and Vietnam. Similar to Mincer's (1958) hedonic earnings function and application in Söderbom and Teal (2004), we construct a labor cost function at the firm level to account for differences in observed human capital. Adding controls for foreign ownership, firm age, and industry, we obtain the following empirical specification: 


$$
\ln \left(w_{i}\right)=\beta_{0}+\beta_{1} \ln \left(L_{i}\right)+\beta_{2} \ln \left(L_{i}\right)^{2}+\beta_{3} \ln \left(E_{i}\right)+\beta_{4} \ln \left(E_{i}\right)^{2}+\theta X_{i}+\epsilon_{i}
$$

where $w_{i}$ is the firm's labor cost per worker, $L_{i}$ is the number of full-time employees, $E_{i}$ is the workers' average educational attainment, $X_{i}$ is a vector of firm controls including firm size, foreign ownership, industry. $\beta_{1-4}$ and $\theta$ are the coefficients to be estimated and $\epsilon_{i}$ is an error term. Squared terms are included to allow for non-linearities. We allow for robust standard errors clustered by country region. ${ }^{9}$

Table 4 shows OLS estimates based on equation (1), plus three more complex specifications that additionally include log GDP per capita, a dummy for Sub-Saharan Africa, and an interaction of that dummy with firm size. Figures 4 and 5 plot adjusted predictions based on these models, differentiating by region and firm ownership. As expected, larger firms and foreign-owned firms pay higher wages, but there is no sign that wages rise more rapidly in Africa with increasing firm size. Measures of educational attainment do not appear to be relevant in determining labor costs mirroring earlier results from ST but this may be due to the crude nature of the variable. Labor in comparators appears to be more expensive. However, after controlling for employment, foreign ownership and other variables as well as GDP per capita, we find a significant markup for sub-Saharan African firms. For firms of similar size (25 employees), African wages are 56 percent higher allowing for GDP per capita.

To overcome the limitations of the data on educational attainment of production workers, we move to a broader specification that proxies unobserved labor quality by firm-level productivity, controlling for firm characteristics and structural determinants. We obtain the following specification:

$$
\ln \left(w_{i}\right)=\beta_{0}+\theta_{1} \ln \left(Y_{i}\right)+\theta_{2} \ln \left(Z_{i}\right)+\theta_{3} X_{i}+\epsilon_{i}
$$

where $w_{i}$ is the firm's labor cost per worker, $X_{i}$ is a vector for firm-level productivity measures including value added per worker and capital per worker, $Z_{i}$ is a vector of countrylevel structural determinants including GDP per capita and a dummy for Sub-Saharan

\footnotetext{
${ }^{9}$ Clustering standard errors by country leaves our key results unchanged. We prefer clustering at the sub-national level to clustering at the country level because we expect the cluster-robust inference to be more accurate in the larger number of clusters (Wooldrige, 2003).
} 
Africa, and $X_{i}$ is a vector of firm controls including firm size, foreign ownership, and firm age. $\theta_{1-3}$ are coefficient vectors and $\epsilon_{i}$ is an error term. Again, we cluster standard errors by country region.

We estimate 11 models, of increasing complexity based on equation (2). The results of OLS estimates for the cost of labor per worker are presented in Table 5. Our dependent variable is calculated by dividing the total cost of labor by the number of full-time equivalent workers. We start with simple estimations of labor cost on GDP per capita, controlling for size, sectors, ownership, and age of the firm. We also include an Africa dummy to see if labor costs are higher in Africa than elsewhere. As we move from left to right in the table, we include an increasing number of interaction terms to include possible cross-effects between location in Africa and size, productivity etc. In addition, we add value added per worker to the right hand side of the equation to examine whether there is a relationship between labor cost and value added and whether this relationship is different in Africa than elsewhere (the ST effect expressed in terms of productivity). Similarly, we include capital per worker, as well as an interaction term.

To better visualize the results, Figures 6 to 8 show adjusted predicted labor costs in Africa versus comparators, based on the regressions of Model 11, Table 5. In each of these figures, all variables in the estimation of Model 11 are held at the global means, except for value added per worker which is allowed to vary around the sample midpoint of $\$ 5,000$. Figure 6 shows about a 50 percent wage premium at the midpoint. Figure 7 shows the predicted labor cost for large and small firms in Africa vs. the comparator countries. Except at very low levels of value added per worker, there is no overlap; even small African firms (with less than 20 workers) are more labor-costly, relative to GDP, than large firms in the comparator countries. The difference in predicted labor cost between African and other firms is, of course, greater for higher levels of value added per worker. Figure 8 shows predicted labor costs, broken down by capital intensity. Again, African firms are more costly than their counterparts in other regions. In addition, there is rather little difference in Africa between high and low capital-intensive firms. But outside Africa, all else equal, firms with lower capital intensity are able to pay their workers relatively less than those that have high capital labor ratios.

Figures 9 to 14 shows industry-specific estimates for each of the sub-sectors. Again, at the sample means we see a large gap between African and non-African wages for a hypothetical firm. The high labor cost estimates are not simply due to differential results by sub-sector. Figure 15 shows predicted unit labor cost disaggregated by capital intensity for different size categories of firms, holding all other variables at the global means. Unit 
labor costs are highest in low capital-intensity firms in Africa and lowest in high capitalintensive firms in other regions. They are almost identical for high capital-intensive African firms and low capital-intensive firms abroad.

Table 6 shows estimates for unit labor costs, tasking as the denominator both sales and value-added. Unit labor costs are higher in Africa than elsewhere, especially relative to sales but also to value-added (as noted above, less specialized African firms tend to have lower sales/value-added ratios). This result is consistent across all 12 models. As expected, they are also higher for micro, small and medium firms relative to large firms. Foreign-owned firms have lower unit labor costs, as do older firms, but the result for the latter is not significant. While unit labor costs are higher in Africa, the differential is smaller than that in labor costs. Part of the labor cost effect is therefore offset by higher labor productivity in Africa, but not all.

\section{How to Account for the Africa effect?}

Our analysis shows that the overall labor cost premium - over 80 percent relative to GDP per capita taking into account sector and size dummies and only a little lower allowing for foreign ownership - has three components. The first is a basic Africa-wide premium of about 42 percent. The second reflects the "enclave effect", relating to the higher productivity of industry in Africa relative to GDP per capita. The third is the "ST effect" within the surveyed industrial sector, which is reflected in the interaction term of the Africa dummy and the number of the employees (Table 5, column 3) and the interaction term of the Africa dummy and valued added per worker (Table 5, column $11)^{10}$. The relative power of the enclave effect and an ST effect may reflect the boundary between formal and informal firms and the limits of the survey, which focuses on the formal sector ${ }^{11}$. Overall, labor costs are especially high in Africa in one particular type of firm: Firms that are productive in terms of high value-added per worker and at the same time less capital intensive.

\footnotetext{
${ }^{10}$ In our preferred specification, the interaction term of the Africa dummy and value added per worker is not significant at $p<0.05$ after clustering standard errors. Using robust standard errors, the interaction term is significant at $p<0.001$.

${ }^{11}$ If pay and productivity levels are substantially lower in the African informal sectors than in the comparator countries, including informal industry would reduce the enclave effect and increase the ST effect. There is no evidence, though, that the surveys systematically exclude smaller African firms relative to firms in comparator countries.
} 
Why is there an enclave effect and a stronger ST effect in Africa? And why does an "Africa effect" remain after allowing for the enclave effect and the ST effect? We have no simple answers to these questions and we are exploring potential explanations and robustness checks. They may indeed reflect several possible factors, with different weights in different countries.

One possibility of course is that GDP per capita in Africa is grossly underestimated. Revisions along the lines of the 60 percent boost in Ghana's GDP in 2010 would eliminate the distinctive Africa story, but it is not clear that GDP is similarly underestimated in other countries. ${ }^{12}$

Another explanation could be the difference in "external costs" faced by firms in Africa (Eifert et al., 2008). Firms can compensate to some extent - for example, they can purchase generators or hold larger inventories - but such adjustment comes at a high cost in terms of factory-floor productivity and profitability. Only the most productive firms can survive these high external costs to operate at scale; they require a workforce with appropriate skills and experience, and therefore constitute "islands of relative productivity" in otherwise very poor countries.

This effect could be compounded by the political economy of enclave business in Africa's small economies and the fact that many of the larger firms are owned by expatriates or ethnic minorities. Studies suggest that in Africa's small markets, firms lobby to preserve market share (Emery, 2003). Maintaining labor payments at a comfortable level in these highly visible firms could be one element in preserving such a political equilibrium.

The results could also reflect labor market factors that raise industrial labor costs in Africa relative to GDP per capita - regulation, unionization, or a lack of potential employees with sufficient skill and experience for formal industry. They could also reflect high search costs due to the sparseness of industry, leading employers to make extra effort to retain proven employees. A first look at indicators does not suggest that overall regulatory differences between the Africa sample and the comparators that drive the results and skills are typically rated low as a constraint in enterprise surveys. South Africa is probably an exception, as seen by active union efforts to close down manufacturing firms that create employment but pay below the official minimum industrial wage (Nattrass and Seekings,

\footnotetext{
${ }^{12}$ Discussions with national income statisticians indicate that GDP might also be underestimated in other African countries for reasons similar to those in Ghana,but the extent of the error is thought to be less - somewhere around 10 percent (personal communication with Misha Belkindas).
} 
$2013)^{13}$. In the lower-income African countries, the low weight on labor issues probably reflects the importance of other constraints, including power, transport and corruption, rather than satisfaction with the level of skills.

Price effects could be another factor. Market-based comparisons of costs and productivity can be misleading if price levels vary a great deal between countries, as in the Balassa Samuelson relationship (Balassa, 1964; Samuelson, 1964; Kravis-Lipsey, 1988; Rogoff, 1996). The generally poorer African countries should have lower price levels, in international PPP Dollars. Real wages would then be higher in a very poor country like Ethiopia than those measured at market exchange rates. Real industrial productivity could be higher as well, to the extent that both input and output prices mirrored the overall national price level to some extent ${ }^{14}$. Conversely, real pay and productivity could be lower in a high-cost country than when measured at market exchange rates.

Data for 188 countries from the Penn World Tables shows that the slope of the relationship between PPP prices and income for African countries is significantly different between African and other countries (Figure 16). Middle-income African countries like South Africa are only slightly more costly than comparable countries outside Africa, but the normal relationship breaks down for low-income Africa. Relative to low-income comparators like Bangladesh, Vietnam and also India, African countries are considerably more costly. Figure 17 shows that the average "Balassa Gap" the extent to which PPP price levels deviate from the global Balassa-Samuelson relationship for the 12 African countries in our sample is 35 percent, relative to zero for the comparators. In absolute terms, and excluding South Africa as a middle-income country, the average PPP for the African countries is about 20 percent higher than the average for the four poorest comparators (Bangladesh, Indonesia, Philippines and Vietnam). Ethiopia stands out as cheap in absolute terms, but its PPP price level is still high-cost relative to the global pattern extrapolated to its level of income.

Relative to other low-income countries, and with the notable exception of Ethiopia, lowincome Africa's high labor costs are therefore partly explained by high PPP price levels. While nominal labor costs are similar to those in the four poorest comparators, real PPP labor costs are actually about 20 percent lower in Africa.

A full discussion of the factors affecting PPP exchange rates is beyond the scope of this

\footnotetext{
${ }^{13}$ Recent wage push in the mining sector as well as measures to increase the minimum wage in agriculture all in the face of very high levels of unemployment also suggest that labor market factors lead high labor costs in this case.

${ }^{14}$ This is more likely if inputs and outputs are domestic goods rather than imported or exported.
} 
paper; they may reflect natural-resource-based exports or aid. They may also reflect large productivity differences in food agriculture, a sector which high transport costs for staples and policy interventions render less-than-fully tradeable. One common explanation for why Africa has failed to industrialize is that successful industrial development needs to be preceded by broad-based agricultural transformation (Johnston and Mellor, 1961). This (a) provides cheap food for domestic consumption enabling a low-cost industrial labor force to survive, (b) drives up incomes of farmers to become consumers of industrial goods and (c) frees up labor for industrial and urban jobs and savings for investments. Using case studies, Henley (2012) suggests that this initial focus on agriculture is what mostly distinguishes East Asian countries from those in Africa.

\section{Conclusion}

The main conclusion of this paper is that industrial labor costs in Sub-Saharan Africa are far higher than might be expected on the basis of GDP per capita. At the median, the two lowest-income comparators - Bangladesh and India - have annual industrial labor costs roughly in line with GDP per capita (with a ratio of labor cost to GDP per capita at 0.98 and 1.41, respectively). At a similar income level, Kenya has a ratio of labor cost to GDP per capita of about 4.37 .

Part of this differential can be accounted for by the higher productivity of "enclaves in the industrial sector in Africa. But an "Africa effect" remains, with an average wage premium of about 50 percent. Our regression results suggest that labor is more costly in firms with relatively low levels of capital intensity - the most desirable kind of firm in a poor, capital-constrained country. These results are not due to different sector weights in Africa and elsewhere, and appear to be robust to controlling for various firm-level and macro characteristics.

Many factors can influence these cross-country patterns. We do not seek to choose between them, or to distinguish between those relating to the labor market itself (restrictive legislation, active trade unions) and other factors, which could differ between countries. High external costs faced by firms could both sustain an industrial enclave, by selecting out all firms with low productivity and at the same time limit the ability of firms to fully adjust to high labor costs by increasing value-added per employee. High PPP exchange rates could also be a factor. The normal pattern of poorer countries being cheaper in PPP terms breaks down for Africa; though not cheap in current dollar terms, labor in low-income Africa is poorer in real terms than in the low-income comparators. Within the 
group of middle-income countries, South Africa's PPP exchange rate is also on the high side relative to countries at similar income levels. In any study of African competitiveness, it is therefore important to understand the reasons behind the PPP exchange rate pattern whether it is due to poor agricultural productivity and high food costs, or natural resource rents or to aid and other exogenous flows that boost the value of African currencies.

Even though reforms and infrastructure investments have the potential to reduce the level of indirect costs faced by African manufacturing industry, without access to competitive labor, African manufacturing firms face an uphill struggle to be globally competitive.

What are the implications? Africa has a young, growing and urbanizing population. Even rapid labor force growth in formal firms would not absorb a high proportion of entrants (Fox, forthcoming), and the labor cost picture suggests that manufacturing industry is not likely to expand formal employment in a dramatic way. What should governments and donors do?

Measures to reduce indirect costs could have a substantial growth and employment effect. Eifert et al. (2008) showed that reducing these costs to the levels in, say, China would save the firm the equivalent of 50 percent of the wage bill. This would about offset the "Africa effect", unless the resulting higher productivity provoked a further increase in wages. One approach that the World Bank and others are trying is to lower costs through agglomeration, with firms and other actors grouped around "growth poles". But if labor costs are higher in Africa and rise more steeply with value added, it is not clear that agglomeration alone will be enough to create a large swath of competitive industry in open, globally-mobile, industrial sectors.

A complementary approach could be to follow the Africa Mining Vision to develop backwards, forward and horizontal linkages with extractive industries. The employment gains could be considerable, as these linkages can provide far more employment than the mining sector itself. Careful analysis of the contribution of the mining industry in Zambia, for example, show indirect job creation at least as large as the direct employment effect (McMahon and Tracy, 2012). In the US, Canada, Australia and other countries, the development of mining has been closely associated with the development of industry and the acquisition of technical capacity. Programs to build the capacity of suppliers and a modicum of supportive industrial and technology policy, for example, offering tax concessions in return for local procurement, processing and training, could help to grow an industrial nucleus with a long-run advantage in local supply. 


\section{References}

African Development Bank, Organisation for Economic Co-operation and Development (OECD), United Nations Development Pgoramme, and United Nations Economic Commission for Africa. African Economic Outlook 2013: Structural Transformation and Natural Resources. OECD Development Centre, Paris.

Agency, M. I. G. (2007). Snapshot Africa: Benchmarking FDI Competitiveness in SubSaharan African Countries. Technical report, The World Bank Group, Washington DC.

Balassa, B. (1964). The Purchasing-Power Parity Doctrine: A Reappraisal. Journal of Political Economy, 72(6):584-596.

Dinh, H. T., Palmade, V., Chandra, V., and Cossar, F. (2012). Light Manufacturing in Africa: Targeted Policies to Enhance Private Investment and Create Jobs. The World Bank, Washington DC.

Eifert, B., Gelb, A. H., and Ramachandran, V. (2008). The Cost of Doing Business in Africa: Evidence from Enterprise Survey Data. World Development, 36(9):1531-1546.

Emery, J. J., Ball, N., and Ramachandran, V. Governance and Private Investment in Africa. In van de Walle, N., editor, Beyond Structural Adjustment: The Institutional Context of African Development. Palgrave Macmillan, New York.

Fox, L. (2011). Why is the Informal Normal in Low-Income Sub-Saharan Africa. Technical report, The World Bank, Washington DC.

Gelb, A., Mengistae, T., Ramachandran, V., and Shah, M. K. (2009). To Formalize or Not to Formalize? Comparisons of Microenterprise Data from Southern and East Africa. Working Paper 175, Center for Global Development, Washington DC.

Gelb, A. H. (2012). Natural Resource Exports and African Development. In Aryeetey, E., Devarajan, S., Kanbur, R., and Kasekende, L., editors, The Oxford Companion to the Economics of Africa, pages 394-401. Oxford University Press, New York.

Henley, D. (2012). The Agrarian Roots of Industrial Growth: Rural Development in South-East Asia and sub-Saharan Africa. Development Policy Review, 30(February Issue Supplement):s25-s47.

Johnston, B. F. and Mellor, J. W. (1961). The Role of Agriculture in Economic Development. American Economic Review, 51(4):566-593.

Kravis, I. B. and Lipsey, R. E. (1988). National Price Levels and the Prices of Tradables and Nontradables. American Economic Review, 78(2, Papers and Proceedings of the One-Hundredth Annual Meeting of the American Economic Association):474-478.

McMahon, G. and Tracy, B. (2012). Firm and Sector-Level Mining Benefits in Zambia. Oil, Gas and Mining (SEGOM) Publication May 2012, The World Bank, Washington DC. 
Mincer, J. (1958). Investment in Human Capital and Personal Income Distribution. Journal of Political Economy, 66(4):281-302.

Nattrass, N. and Seekings, J. (2013). Job Destruction in the South African Clothing Industry: How an Alliance of Organised Labour, the State and Some Firms is Undermining Labour-Intensive Growth. CDE Focus January 2013, Centre for Development and Enterprise, Johannesburg.

Ramachandran, V., Shah, M. K., and Tata, G. (2007). How Does Influence-Peddling Impact Industrial Competition ? Evidence from Enterprise Surveys in Africa. Working Paper 127, Center for Global Development, Washington DC.

Rodrik, D. (2008). The Real Exchange Rate and Economic Growth. Brookings Papers on Economic Activity, (2):365-412.

Rogoff, K. (1996). The Purchasing Power Parity Puzzle. Journal of Economic Literature, 34(2):647-668.

Rotunno, L., Vzina, P.-L., and Wang, Z. (2012). The Rise and Fall of (Chinese) African Apparel Exports. CSAE Working Paper WPS/2012-12, Centre for the Study of African Economies, University of Oxford, Oxford.

Söderbom, Mans and Teal, Francis, year $=2004$, p. . . Size and Efficiency in African Manufacturing Firms: Evidence from Firm-Level Panel Data. Journal of Development Economics, 73(1).

The World Bank (2009a). Mauritius Investment Climate Assessment. Report 52794, The World Bank Group, Washington DC.

The World Bank (2009b). Mozambique Investment Climate Assessment - Sustaining and Boradening Growth. Report 51326, The World Bank Group, Washington DC.

The World Bank (2011). Improving the Business Environment for Growth and Job Creation in South Africa: The Second Investment Climate Assessment. Report 69747, The World Bank Group, Washington DC.

The World Bank (2012a). Country Partnership Strategy for the Republic of Mozambique FY2012-15. Report 66813-MZ, The World Bank Group, Washington DC.

The World Bank (2012b). World Development Report 2013: Jobs. The World Bank Group, Washington DC.

Tybout, J. (2000). Manufacturing Firms in Developing Countries: How Well Do They Do, and Why? Journal of Economic Literature, XXXVIII(March):11-44.

United Nations Economic Commission for Africa and African Union (2007). Economic Report on Africa 200\%: Accelerating Africa's Development through Diversification. United Nations Economic Commission for Africa, Addis Ababa.

Wooldridge, J. M. (2003). Cluster-Sample Methods in Applied Econometrics. American Economic Review, 93(2):133-138. 


\section{A. Tables}

Table 1: Macroeconomic Indicators

\begin{tabular}{|c|c|c|c|c|c|c|c|c|c|c|c|c|}
\hline \multirow[b]{2}{*}{$\begin{array}{l}\text { Region } \\
\text { (1) }\end{array}$} & \multirow[b]{2}{*}{$\begin{array}{l}\text { Country } \\
\text { (2) }\end{array}$} & \multirow[b]{2}{*}{$\begin{array}{l}\text { Survey } \\
\text { Year }^{(1)} \\
\text { (3) }\end{array}$} & \multirow[b]{2}{*}{$\begin{array}{l}\text { \# of } \\
\text { firms } \\
\text { (4) }\end{array}$} & \multicolumn{9}{|c|}{ Macroeconomic Indicators } \\
\hline & & & & $\begin{array}{l}\text { GDP/capita } \\
\text { USD } \\
\text { (5) }\end{array}$ & $\begin{array}{l}\text { Mfct Value Added } \\
\% \text { of GDP } \\
\text { (6) }\end{array}$ & $\begin{array}{l}\text { Total Exports } \\
\% \text { of GDP } \\
\text { (7) }\end{array}$ & $\begin{array}{l}\text { Mfct Exports } \\
\% \text { of exports } \\
\text { (8) }\end{array}$ & $\begin{array}{l}\text { PPP Price Level } \\
(2005 \text { ICP/WDI) } \\
(2) \\
(9)\end{array}$ & $\begin{array}{l}\text { PPP Price Level } \\
\left(2005 \text { ICP/PWT }^{(3)}\right. \\
(10)\end{array}$ & $\begin{array}{l}\text { Employment to } \\
\text { population ratio } \\
\text { (11) }\end{array}$ & $\begin{array}{l}\text { Labor force } \\
\text { participation rate } \\
\text { (12) }\end{array}$ & $\begin{array}{l}\text { Net Food Imports } \\
\text { USD/cap (3 vr ava) } \\
\text { (13) }\end{array}$ \\
\hline \multirow{11}{*}{$\begin{array}{l}\text { Sub-Saharan } \\
\text { Africa }\end{array}$} & Angola & 2006 & 191 & 1,022 & 3.5 & 79.3 & & 51.04 & 85.64 & 64.8 & 70.2 & 50.56 \\
\hline & Ethiopia & 2006 & 248 & 170 & 4.8 & 15.1 & 4.6 & 26.05 & 33.62 & 80.1 & 84.6 & 1.66 \\
\hline & Ghana & 2007 & 273 & 345 & 10.2 & 25.2 & 30.9 & 70.99 & 53.62 & 66.4 & 68.8 & -18.22 \\
\hline & Kenya & 2007 & 363 & 498 & 11.5 & 26.4 & 35.7 & 42.75 & 50.92 & 58.9 & 65.5 & 3.97 \\
\hline & Mali & 2007 & 279 & 288 & 3.1 & 32.1 & 9.4 & 46.29 & 50.73 & 47.5 & 52.0 & 11.61 \\
\hline & Mozambique & 2007 & 307 & 369 & 16.0 & 38.4 & 5.0 & 45.47 & 49.75 & 78.9 & 85.3 & 11.34 \\
\hline & Nigeria & 2007 & 868 & 517 & 2.6 & 42.9 & 1.3 & 54.21 & 61.53 & 50.9 & 54.9 & 20.65 \\
\hline & South Africa & 2007 & 645 & 4,003 & 17.5 & 30.0 & 52.9 & 58.99 & 73.79 & 40.0 & 53.7 & -6.83 \\
\hline & Tanzania & 2006 & 242 & 426 & 8.7 & 20.8 & 14.0 & 35.04 & 41.12 & 79.0 & 89.5 & 5.79 \\
\hline & Uganda & 2006 & 280 & 340 & 7.5 & 14.2 & 11.5 & 35.66 & 36.94 & 77.0 & 78.6 & 8.45 \\
\hline & Zambia & 2007 & 286 & 417 & 11.6 & 38.5 & 5.8 & 73.54 & 72.84 & 67.1 & 79.8 & -0.09 \\
\hline \multirow{3}{*}{$\begin{array}{l}\text { East Asia and } \\
\text { Pacific }\end{array}$} & Indonesia & 2009 & 494 & 1,187 & 27.8 & 29.8 & 38.8 & 56.02 & 54.41 & 61.7 & 67.3 & -32.67 \\
\hline & Philippines & 2009 & 327 & 1,483 & 22.8 & 36.9 & 83.3 & 52.41 & 54.35 & 59.2 & 63.8 & 17.44 \\
\hline & Vietnam & 2009 & 520 & 740 & 20.3 & 77.9 & 55.2 & 37.75 & 37.04 & 75.1 & 77.0 & -11.93 \\
\hline \multirow{3}{*}{$\begin{array}{l}\text { Europe and } \\
\text { Central Asia }\end{array}$} & Russia & 2009 & 228 & 3,259 & 17.6 & 30.2 & 17.0 & 54.63 & 66.69 & 58.3 & 62.1 & 85.97 \\
\hline & Turkey & 2008 & 420 & 6,006 & 19.1 & 22.3 & 81.7 & 66.30 & 78.90 & 42.2 & 47.0 & -30.13 \\
\hline & Ukraine & 2008 & 137 & 1,270 & 23.1 & 44.8 & 74.5 & 44.10 & 38.52 & 54.5 & 58.2 & -70.74 \\
\hline \multirow{5}{*}{$\begin{array}{l}\text { Latin America } \\
\text { and the } \\
\text { Caribbean }\end{array}$} & Brazil & 2009 & 712 & 4,849 & 15.4 & 13.4 & 47.8 & 73.63 & 92.41 & 63.8 & 69.4 & -140.59 \\
\hline & Chile & 2006 & 424 & 6,396 & 16.3 & 41.3 & 12.9 & 59.61 & 66.79 & 50.8 & 55.2 & -124.87 \\
\hline & Colombia & 2010 & 506 & 3,557 & 14.2 & 16.1 & 28.5 & 56.50 & 63.22 & 58.7 & 66.7 & -2.35 \\
\hline & Mexico & 2006 & 828 & 6,750 & 18.4 & 27.1 & 77.1 & 65.40 & 68.43 & 58.4 & 60.5 & 33.44 \\
\hline & Uruguay & 2006 & 151 & 7,861 & 17.1 & 30.4 & 31.9 & 54.24 & 61.06 & 57.0 & 62.9 & -437.83 \\
\hline \multirow[t]{2}{*}{ South Asia } & Bangladesh & 2007 & 1162 & 519 & 17.2 & 19.0 & 91.3 & 34.34 & 34.74 & 67.6 & 70.6 & 12.47 \\
\hline & India & 2005 & 2286 & 565 & 15.4 & 19.3 & 71.1 & 33.13 & - & 58.2 & 63.1 & - \\
\hline
\end{tabular}

Notes:

All currency values are in constant 2005 USD.

(1) Refers to survey year for better comparability with other studies. All calculations are based on actual surveyed fiscal year according to survey codebooks

(2) Price level of GDP $(U S=100)$ in survey year. Ratio of the 2005 ICP PPP conversion factor to the relevant market exchange rate, estimate from World Development Indicators (3) Price level of GDP (US = 100) in survey year. Ratio of the 2005 ICP PPP conversion factor to the relevant market exchange rate, estimate from Penn World Table.

(5) Empoyment to population ralio is the proporion of a countr's population aged ls years and older hat is employed

(6) Net food imports are imports minus exports of all food excluding fish based on FAO data, averaged across three years around the survey year

Source: Authors' calculations, based on World Bank Enterprise Surveys data, World Bank World Development Indicators, UN COMTRADE, FAO, IMF. 
Table 2: Firm Sample Characteristics

\begin{tabular}{|c|c|c|c|c|c|c|c|c|c|c|c|c|}
\hline \multirow{2}{*}{ Region } & \multirow{2}{*}{ Country } & \multirow{2}{*}{$\begin{array}{l}\text { Survey } \\
\text { Year }^{(1)}\end{array}$} & \multirow{2}{*}{$\begin{array}{c}\text { \# of } \\
\text { firms }\end{array}$} & \multicolumn{6}{|c|}{ Firm Size $^{(2)}$} & \multicolumn{2}{|c|}{ Firm Age } & \multirow{2}{*}{$\frac{\text { Exporters }^{(3)}}{\% \text { of total }}$} \\
\hline & & & & $\overline{\text { mean }}$ & median & $\%$ micro & $\%$ small & $\%$ medium & $\%$ large & mean & $\overline{\text { median }}$ & \\
\hline $\begin{array}{l}\text { Sub-Saharan } \\
\text { Africa }\end{array}$ & $\begin{array}{l}\text { Angola } \\
\text { Ethiopia } \\
\text { Ghana } \\
\text { Kenya } \\
\text { Mali } \\
\text { Mozambique } \\
\text { Nigeria } \\
\text { Senegal } \\
\text { SouthAfrica } \\
\text { Tanzania } \\
\text { Uganda } \\
\text { Zambia }\end{array}$ & $\begin{array}{l}2006 \\
2006 \\
2007 \\
2007 \\
2007 \\
2007 \\
2007 \\
2007 \\
2007 \\
2006 \\
2006 \\
2007\end{array}$ & $\begin{array}{l}191 \\
248 \\
273 \\
363 \\
279 \\
307 \\
868 \\
241 \\
645 \\
242 \\
280 \\
286\end{array}$ & $\begin{array}{l}15 \\
72 \\
29 \\
126 \\
13 \\
22 \\
20 \\
17 \\
97 \\
44 \\
33 \\
60\end{array}$ & $\begin{array}{l}11 \\
14 \\
11 \\
50 \\
7 \\
10 \\
12 \\
10 \\
32 \\
15 \\
15 \\
22\end{array}$ & $\begin{array}{l}0.04 \\
0.13 \\
0.13 \\
0.03 \\
0.16 \\
0.25 \\
0.08 \\
0.11 \\
0.06 \\
0.09 \\
0.06 \\
0.10\end{array}$ & $\begin{array}{l}0.83 \\
0.49 \\
0.56 \\
0.29 \\
0.70 \\
0.44 \\
0.68 \\
0.74 \\
0.31 \\
0.52 \\
0.58 \\
0.38\end{array}$ & $\begin{array}{l}0.12 \\
0.28 \\
0.24 \\
0.40 \\
0.13 \\
0.28 \\
0.23 \\
0.13 \\
0.39 \\
0.29 \\
0.30 \\
0.37\end{array}$ & $\begin{array}{l}0.02 \\
0.10 \\
0.07 \\
0.28 \\
0.00 \\
0.03 \\
0.01 \\
0.02 \\
0.24 \\
0.11 \\
0.06 \\
0.15\end{array}$ & $\begin{array}{l}8.8 \\
- \\
15.7 \\
23 \\
10.3 \\
15.4 \\
10.2 \\
12.1 \\
18.7 \\
13.7 \\
12.5 \\
14.4\end{array}$ & $\begin{array}{l}5 \\
- \\
12 \\
20 \\
7 \\
12 \\
8 \\
9 \\
13 \\
11 \\
10 \\
9.5\end{array}$ & $\begin{array}{l}0.01 \\
0.07 \\
0.20 \\
0.44 \\
0.13 \\
0.04 \\
0.03 \\
0.13 \\
0.30 \\
0.14 \\
0.14 \\
0.18\end{array}$ \\
\hline $\begin{array}{l}\text { East Asia and } \\
\text { Pacific }\end{array}$ & $\begin{array}{l}\text { Indonesia } \\
\text { Philippines } \\
\text { Vietnam }\end{array}$ & $\begin{array}{l}2009 \\
2009 \\
2009\end{array}$ & $\begin{array}{l}494 \\
327 \\
520\end{array}$ & $\begin{array}{l}217 \\
132 \\
142\end{array}$ & $\begin{array}{l}70 \\
45 \\
33\end{array}$ & $\begin{array}{l}0.01 \\
0.03 \\
0.05\end{array}$ & $\begin{array}{l}0.21 \\
0.26 \\
0.32\end{array}$ & $\begin{array}{l}0.43 \\
0.43 \\
0.31\end{array}$ & $\begin{array}{l}0.36 \\
0.28 \\
0.32\end{array}$ & $\begin{array}{l}17.8 \\
20.2 \\
11.5\end{array}$ & $\begin{array}{l}15 \\
17 \\
8\end{array}$ & $\begin{array}{l}0.21 \\
0.38 \\
0.47\end{array}$ \\
\hline $\begin{array}{l}\text { Europe and } \\
\text { Central Asia }\end{array}$ & $\begin{array}{l}\text { Russia } \\
\text { Turkey } \\
\text { Ukraine }\end{array}$ & $\begin{array}{l}2009 \\
2008 \\
2008\end{array}$ & $\begin{array}{l}228 \\
420 \\
137\end{array}$ & $\begin{array}{l}217 \\
132 \\
142\end{array}$ & $\begin{array}{l}70 \\
45 \\
33\end{array}$ & $\begin{array}{l}0.01 \\
0.03 \\
0.05\end{array}$ & $\begin{array}{l}0.21 \\
0.26 \\
0.32\end{array}$ & $\begin{array}{l}0.43 \\
0.43 \\
0.31\end{array}$ & $\begin{array}{l}0.36 \\
0.28 \\
0.32\end{array}$ & $\begin{array}{l}19.6 \\
18 \\
19.2\end{array}$ & $\begin{array}{l}14 \\
15 \\
13\end{array}$ & $\begin{array}{l}0.27 \\
0.63 \\
0.34\end{array}$ \\
\hline $\begin{array}{l}\text { Latin America } \\
\text { and the } \\
\text { Caribbean }\end{array}$ & $\begin{array}{l}\text { Argentina } \\
\text { Brazil } \\
\text { Chile } \\
\text { Colombia } \\
\text { Mexico } \\
\text { Uruguay }\end{array}$ & $\begin{array}{l}2006 \\
2009 \\
2006 \\
2010 \\
2006 \\
2006\end{array}$ & $\begin{array}{l}370 \\
712 \\
424 \\
506 \\
828 \\
151\end{array}$ & $\begin{array}{l}84 \\
152 \\
68 \\
93 \\
84 \\
33\end{array}$ & $\begin{array}{l}28 \\
30 \\
27 \\
30 \\
20 \\
20\end{array}$ & $\begin{array}{l}0.05 \\
0.02 \\
0.02 \\
0.07 \\
0.08 \\
0.07\end{array}$ & $\begin{array}{l}0.34 \\
0.38 \\
0.38 \\
0.33 \\
0.43 \\
0.47\end{array}$ & $\begin{array}{l}0.42 \\
0.42 \\
0.44 \\
0.39 \\
0.29 \\
0.40\end{array}$ & $\begin{array}{l}0.19 \\
0.19 \\
0.17 \\
0.21 \\
0.20 \\
0.05\end{array}$ & $\begin{array}{l}32.1 \\
22.3 \\
28.9 \\
23.7 \\
18.7 \\
28.9\end{array}$ & $\begin{array}{l}28 \\
18 \\
24 \\
20 \\
15 \\
23\end{array}$ & $\begin{array}{l}0.52 \\
0.25 \\
0.29 \\
0.45 \\
0.15 \\
0.42\end{array}$ \\
\hline South Asia & Bangladesh & 2007 & 1162 & 268 & 61 & 0.00 & 0.30 & 0.26 & 0.44 & 17.6 & 15 & 0.38 \\
\hline & India ${ }^{(4)}$ & 2005 & 2286 & 92 & 18 & 0.06 & 0.45 & 0.29 & 0.13 & 16.7 & 14 & 0.26 \\
\hline
\end{tabular}

Notes: $\quad$ All currency values are in constant 2005 USD.

(1) Refers to survey year for better comparability with other studies, calculations are based on surveyed fiscal year according to single codebooks.

(2) Micro: $\leq 5$ employees, small: 6-20 employees, medium: 21-100 employees, large: >100 employees

(3) We define a firm as an exporter when any percentage of sales is indirectly or directly exported.

(4) India's survey does not follow the global methodology. Results for India are not corrected for outliers.

Source: Authors' calculations, based on World Bank Enterprise Surveys data. 
Table 3: Firm-level productivity measures

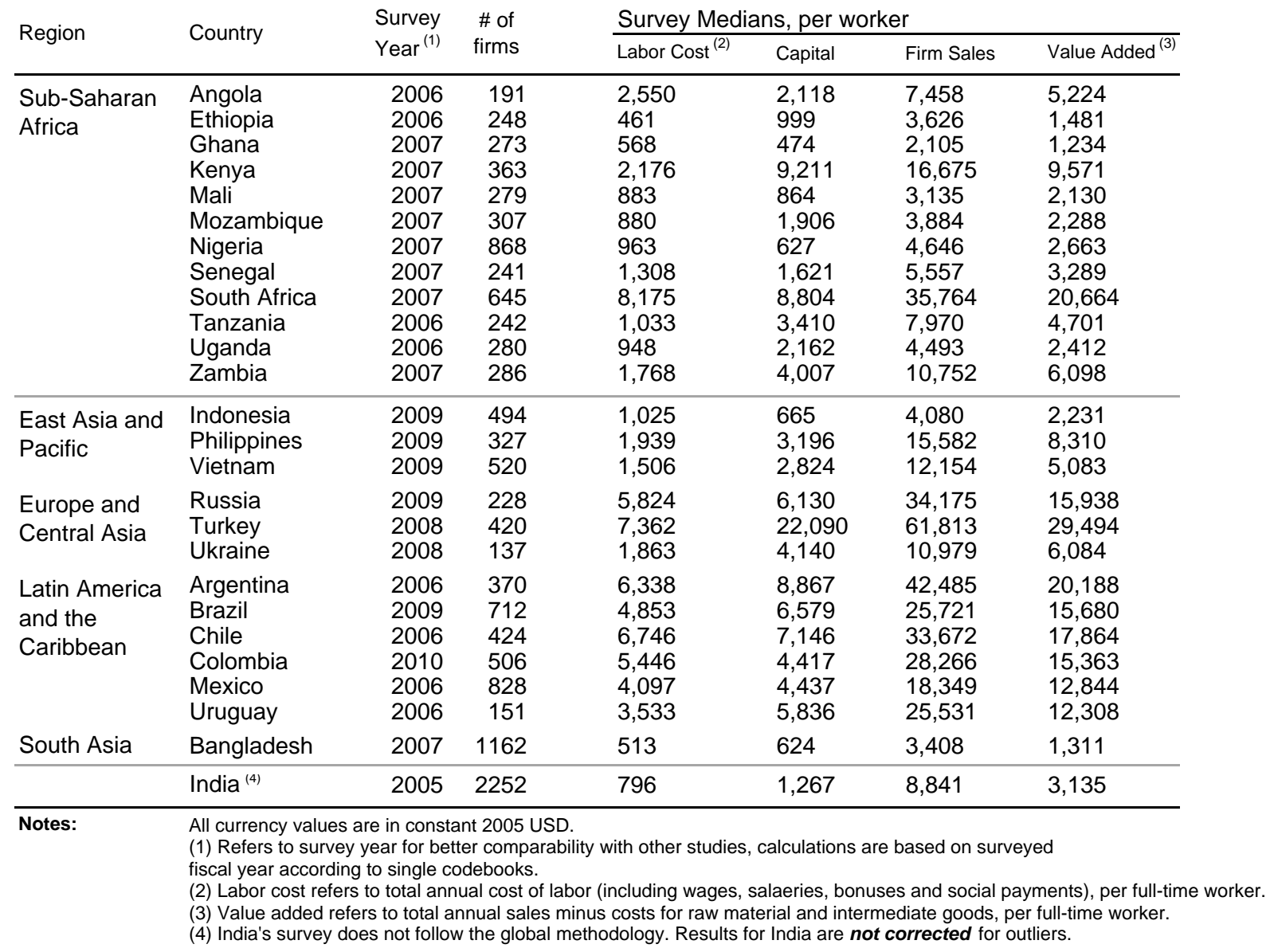

Source: Authors' calculations, based on World Bank Enterprise Surveys data. 
Table 4: OLS Estimates of Mincer-type Earnings Function Models

\begin{tabular}{|c|c|c|c|c|}
\hline \multirow[t]{2}{*}{ Dependent variable: } & \multicolumn{4}{|c|}{ log labor cost per worker } \\
\hline & $(1)$ & $(2)$ & (3) & $(4)$ \\
\hline log Firm Size & $\begin{array}{l}0.598^{\star * *} \\
(0.0834)\end{array}$ & $\begin{array}{l}0.527^{\star \star * *} \\
(0.138)\end{array}$ & $\begin{array}{l}0.475^{\star \star \star *} \\
(0.111)\end{array}$ & $\begin{array}{l}0.526^{\star \star *} \\
(0.129)\end{array}$ \\
\hline$(\text { Log Firm Size })^{2}$ & $\begin{array}{l}-0.0580^{* \star *} \\
(0.00963)\end{array}$ & $\begin{array}{l}-0.0537^{\star \star \star} \\
(0.0136)\end{array}$ & $\begin{array}{l}-0.0476^{\star \star \star} \\
(0.0120)\end{array}$ & $\begin{array}{l}-0.0498^{\star \star \star} \\
(0.0141)\end{array}$ \\
\hline Average education of workers & $\begin{array}{l}0.120 \\
(0.217)\end{array}$ & $\begin{array}{l}0.0167 \\
(0.207)\end{array}$ & $\begin{array}{l}-0.0903 \\
(0.170)\end{array}$ & $\begin{array}{l}-0.0479 \\
(0.158)\end{array}$ \\
\hline (Average education of workers) $^{2}$ & $\begin{array}{l}-0.00872 \\
(0.0337)\end{array}$ & $\begin{array}{l}0.00637 \\
(0.0313)\end{array}$ & $\begin{array}{l}0.0287 \\
(0.0242)\end{array}$ & $\begin{array}{l}0.0256 \\
(0.0226)\end{array}$ \\
\hline Firm age & $\begin{array}{l}0.0109 \\
(0.00710)\end{array}$ & $\begin{array}{l}0.00982 \\
(0.00664)\end{array}$ & $\begin{array}{l}0.00437 \\
(0.00474)\end{array}$ & $\begin{array}{l}0.00294 \\
(0.00468)\end{array}$ \\
\hline$(\text { Firm age })^{2}$ & $\begin{array}{l}-0.00173 \\
(0.00536)\end{array}$ & $\begin{array}{l}-0.000876 \\
(0.00515)\end{array}$ & $\begin{array}{l}0.00138 \\
(0.00420)\end{array}$ & $\begin{array}{l}0.00158 \\
(0.00413)\end{array}$ \\
\hline Foreign-ownership & $\begin{array}{l}0.304^{*} \\
(0.143)\end{array}$ & $\begin{array}{l}0.350^{*} \\
(0.147)\end{array}$ & $\begin{array}{l}0.414^{\star \star} \\
(0.142)\end{array}$ & $\begin{array}{l}0.402^{\star *} \\
(0.136)\end{array}$ \\
\hline log GDP per capita (constant 2005 US\$) & & & $\begin{array}{l}0.374^{*} \\
(0.145)\end{array}$ & $\begin{array}{l}0.539^{\star} \\
(0.213)\end{array}$ \\
\hline Sub-Saharan Africa dummy & & $\begin{array}{l}-0.358 \\
(0.323)\end{array}$ & & $\begin{array}{l}0.510 \\
(0.282)\end{array}$ \\
\hline Sub-Saharan Africa dummy ${ }^{x}$ log Employment & & $\begin{array}{l}0.00216 \\
(0.0635)\end{array}$ & & $\begin{array}{l}-0.0167 \\
(0.0529)\end{array}$ \\
\hline Constant & $\begin{array}{l}5.614^{\star \star \star} \\
(0.355) \\
\end{array}$ & $\begin{array}{l}6.086^{\star \star \star} \\
(0.494) \\
\end{array}$ & $\begin{array}{l}3.571^{\star \star \star} \\
(0.904) \\
\end{array}$ & $\begin{array}{l}2.025 \\
(1.478) \\
\end{array}$ \\
\hline Industry dummies & Yes & Yes & Yes & Yes \\
\hline Observations & 3141 & 3141 & 3141 & 3141 \\
\hline
\end{tabular}

Note: Continuous independent variables are centered at the group mean of Sub-Saharan Africa.

Robust standard errors, clustered by region, shown in parentheses: ${ }^{*} p<0.05,{ }^{* *} p<0.01,{ }^{* * *} p<0.001$.

Source: Authors' calculations, based on World Bank Enterprise Surveys data. 
Table 5: OLS Estimates of Value-Added Labor Cost Models

Dependent variable: $\quad$ log labor cost per worker

\begin{tabular}{|c|c|c|c|c|c|c|c|c|c|c|c|}
\hline & & & & & & & & & & & \\
\hline & $(1)$ & $(2)$ & (3) & (4) & $(5)$ & $(6)$ & $(7)$ & $(8)$ & $(9)$ & $(10)$ & $(11)$ \\
\hline \multicolumn{12}{|l|}{ Macro } \\
\hline log GDP per capita & $\begin{array}{l}0.836^{\star * *} \\
(0.0435)\end{array}$ & $\begin{array}{l}0.830^{\star * *} \\
(0.0415)\end{array}$ & $\begin{array}{l}0.819^{* * *} \\
(0.0431)\end{array}$ & $\begin{array}{l}0.830^{\star * *} \\
(0.0412)\end{array}$ & $\begin{array}{l}0.387^{\star \star \star} \\
(0.0452)\end{array}$ & $\begin{array}{l}0.387^{\star * *} \\
(0.0455)\end{array}$ & $\begin{array}{l}0.663^{* * *} \\
(0.0470)\end{array}$ & $\begin{array}{l}0.659^{* * *} \\
(0.0472)\end{array}$ & $\begin{array}{l}0.377^{\star * *} \\
(0.0458)\end{array}$ & $\begin{array}{l}0.377^{\star * *} \\
(0.0452)\end{array}$ & $\begin{array}{l}0.375^{\star * *} \\
(0.0459)\end{array}$ \\
\hline Sub-Saharan Africa dummy & $\begin{array}{l}0.870^{* * *} \\
(0.0916)\end{array}$ & $\begin{array}{l}0.860 * * * \\
(0.0894)\end{array}$ & $\begin{array}{l}0.760^{* * *} \\
(0.0974)\end{array}$ & $\begin{array}{l}0.862^{* * *} \\
(0.0913)\end{array}$ & $\begin{array}{l}0.444^{* * *} \\
(0.0475)\end{array}$ & $\begin{array}{l}0.438^{* * *} \\
(0.0412)\end{array}$ & $\begin{array}{l}0.679 * * * \\
(0.0635)\end{array}$ & $\begin{array}{l}0.687^{* * *} \\
(0.0653)\end{array}$ & $\begin{array}{l}0.424^{* * *} \\
(0.0408)\end{array}$ & $\begin{array}{l}0.433^{* * *} \\
(0.0497)\end{array}$ & $\begin{array}{l}0.420^{* * *} \\
(0.0409)\end{array}$ \\
\hline \multicolumn{12}{|l|}{ Firm characteristics } \\
\hline Size dummy: $<5$ & $\begin{array}{l}-0.588^{* \star *} \\
(0.0877)\end{array}$ & $\begin{array}{l}-0.509^{\star * \star} \\
(0.0890)\end{array}$ & & $\begin{array}{l}-0.510^{\star * *} \\
(0.0881)\end{array}$ & $\begin{array}{l}-0.129^{*} \\
(0.0601)\end{array}$ & $\begin{array}{l}-0.119^{*} \\
(0.0503)\end{array}$ & $\begin{array}{l}-0.344^{\star * *} \\
(0.0883)\end{array}$ & $\begin{array}{l}-0.365^{\star \star *} \\
(0.0882)\end{array}$ & $\begin{array}{l}-0.107^{*} \\
(0.0515)\end{array}$ & $\begin{array}{l}-0.127^{*} \\
(0.0594)\end{array}$ & $\begin{array}{l}-0.101^{*} \\
(0.0508)\end{array}$ \\
\hline Size dummy: 6-20 & $\begin{array}{l}-0.425^{\star \star *} \\
(0.0609)\end{array}$ & $\begin{array}{l}-0.352^{* * *} \\
(0.0592)\end{array}$ & & $\begin{array}{l}-0.353^{* * *} \\
(0.0590)\end{array}$ & $\begin{array}{l}-0.0825^{*} \\
(0.0387)\end{array}$ & $\begin{array}{l}-0.0766^{*} \\
(0.0354)\end{array}$ & $\begin{array}{l}-0.222^{* \star *} \\
(0.0620)\end{array}$ & $\begin{array}{l}-0.237^{* * *} \\
(0.0646)\end{array}$ & $\begin{array}{l}-0.0641 \\
(0.0377)\end{array}$ & $\begin{array}{l}-0.0775 \\
(0.0414)\end{array}$ & $\begin{array}{l}-0.0649 \\
(0.0389)\end{array}$ \\
\hline Size dummy: $21-100$ & $\begin{array}{l}-0.129^{*} \\
(0.0579)\end{array}$ & $\begin{array}{l}-0.0863 \\
(0.0553)\end{array}$ & & $\begin{array}{l}-0.0860 \\
(0.0553)\end{array}$ & $\begin{array}{l}-0.00445 \\
(0.0346)\end{array}$ & $\begin{array}{l}-0.00157 \\
(0.0327)\end{array}$ & $\begin{array}{l}-0.0421 \\
(0.0536)\end{array}$ & $\begin{array}{l}-0.0482 \\
(0.0543)\end{array}$ & $\begin{array}{l}0.00339 \\
(0.0339)\end{array}$ & $\begin{array}{l}-0.00231 \\
(0.0361)\end{array}$ & $\begin{array}{l}0.00456 \\
(0.0342)\end{array}$ \\
\hline Foreign ownership dummy & & $\begin{array}{l}0.366^{* * *} \\
(0.0644)\end{array}$ & $\begin{array}{l}0.464^{* * *} \\
(0.0633)\end{array}$ & $\begin{array}{l}0.367^{* * *} \\
(0.0655)\end{array}$ & $\begin{array}{l}0.0522 \\
(0.0447)\end{array}$ & $\begin{array}{l}0.0507 \\
(0.0444)\end{array}$ & $\begin{array}{l}0.227^{* * *} \\
(0.0581)\end{array}$ & $\begin{array}{l}0.237^{\star * *} \\
(0.0557)\end{array}$ & $\begin{array}{l}0.0391 \\
(0.0451)\end{array}$ & $\begin{array}{l}0.0467 \\
(0.0434)\end{array}$ & $\begin{array}{l}0.0478 \\
(0.0443)\end{array}$ \\
\hline log Firm age & & $\begin{array}{l}0.0471 \\
(0.0250)\end{array}$ & $\begin{array}{l}0.0875^{* *} \\
(0.0269)\end{array}$ & $\begin{array}{l}0.0522 \\
(0.0373)\end{array}$ & $\begin{array}{l}0.0195 \\
(0.0150)\end{array}$ & $\begin{array}{l}0.0202 \\
(0.0150)\end{array}$ & $\begin{array}{l}0.0223 \\
(0.0191)\end{array}$ & $\begin{array}{l}0.0211 \\
(0.0191)\end{array}$ & $\begin{array}{l}0.0156 \\
(0.0147)\end{array}$ & $\begin{array}{l}0.0144 \\
(0.0146)\end{array}$ & $\begin{array}{l}0.0167 \\
(0.0145)\end{array}$ \\
\hline Number of employees & & & $\begin{array}{l}0.00000356 \\
(0.0000484)\end{array}$ & & & & & & & & \\
\hline $\mathrm{SSA}^{\times}$number of employees & & & $\begin{array}{l}0.000401^{* *} \\
(0.000131)\end{array}$ & & & & & & & & \\
\hline SSA $\times \log$ firm age & & & & $\begin{array}{l}-0.0117 \\
(0.0476)\end{array}$ & & & & & & & \\
\hline \multicolumn{12}{|l|}{ Firm productivity metrics } \\
\hline $\log$ value added per worker & & & & & $\begin{array}{l}0.531^{* * *} \\
(0.0674)\end{array}$ & $\begin{array}{l}0.524^{* * *} \\
(0.0488)\end{array}$ & & & $\begin{array}{l}0.483^{* * *} \\
(0.0443)\end{array}$ & $\begin{array}{l}0.486^{* * *} \\
(0.0358)\end{array}$ & $\begin{array}{l}0.461^{* * *} \\
(0.0424)\end{array}$ \\
\hline $\mathrm{SSA}^{\times} \log$ value added p. wk & & & & & & $\begin{array}{l}0.0234 \\
(0.0416)\end{array}$ & & & $\begin{array}{l}0.0189 \\
(0.0423)\end{array}$ & & $\begin{array}{l}0.0831 \\
(0.0438)\end{array}$ \\
\hline $\log$ capital per worker & & & & & & & $\begin{array}{l}0.211^{* * *} \\
(0.0288)\end{array}$ & $\begin{array}{l}0.236^{* * *} \\
(0.0396)\end{array}$ & $\begin{array}{l}0.0570^{* * *} \\
(0.0124)\end{array}$ & $\begin{array}{l}0.0715^{\star * *} \\
(0.0195)\end{array}$ & $\begin{array}{l}0.0841^{* * *} \\
(0.0179)\end{array}$ \\
\hline $\mathrm{SSA}^{\times} \log$ capital per wk & & & & & & & & $\begin{array}{l}-0.0695 \\
(0.0353)\end{array}$ & & $\begin{array}{l}-0.0364 \\
(0.0237)\end{array}$ & $\begin{array}{l}-0.0716^{\star \star *} \\
(0.0191)\end{array}$ \\
\hline Constant & $\begin{array}{l}6.742^{\star * *} \\
(0.110)\end{array}$ & $\begin{array}{l}6.658^{* * *} \\
(0.106)\end{array}$ & $\begin{array}{l}6.468^{* * *} \\
(0.0896)\end{array}$ & $\begin{array}{l}6.657^{* * *} \\
(0.108)\end{array}$ & $\begin{array}{l}6.942^{* * *} \\
(0.0435)\end{array}$ & $\begin{array}{l}6.940^{* * *} \\
(0.0455)\end{array}$ & $\begin{array}{l}6.763^{* * *} \\
(0.0816)\end{array}$ & $\begin{array}{l}6.771^{* * *} \\
(0.0741)\end{array}$ & $\begin{array}{l}6.946^{* * *} \\
(0.0453)\end{array}$ & $\begin{array}{l}6.951^{* * *} \\
(0.0415)\end{array}$ & $\begin{array}{l}6.950^{* * *} \\
(0.0452)\end{array}$ \\
\hline Industry dummies & Yes & Yes & Yes & Yes & Yes & Yes & Yes & Yes & Yes & Yes & Yes \\
\hline Observations & 10502 & 10195 & 10195 & 10195 & 10172 & 10172 & 10195 & 10195 & 10172 & 10172 & 10172 \\
\hline
\end{tabular}

Note: All currency values are in constant 2005 USD. GDP per capita at market exchange rates. Continuous independent variables are centered at the group mean of Sub-Saharan Africa. Robust standard errors, clustered by region, shown in parentheses: ${ }^{*} p<0.05,{ }^{* *} p<0.01,{ }^{* * *} p<0.001$.

Source: Authors' calculations, based on World Bank Enterprise Surveys data. 
Table 6: OLS Estimates of Unit Labor Cost Models

\begin{tabular}{|c|c|c|c|c|c|c|c|c|c|c|c|c|}
\hline \multirow{2}{*}{ Dependent variable: } & \multicolumn{6}{|c|}{ ULC (based on sales) } & \multicolumn{6}{|c|}{ ULC (based on value added) } \\
\hline & $(1)$ & $(2)$ & $(3)$ & $(4)$ & $(5)$ & $(6)$ & $(7)$ & $(8)$ & $(9)$ & $(10)$ & $(11)$ & $(12)$ \\
\hline \multicolumn{13}{|l|}{ Macro } \\
\hline $\log$ GDP per capita & $\begin{array}{l}0.0926^{* *} \\
(0.0296)\end{array}$ & $\begin{array}{l}0.0849^{* *} \\
(0.0278)\end{array}$ & $\begin{array}{l}0.0925^{* *} \\
(0.0293)\end{array}$ & $\begin{array}{l}0.0849^{* *} \\
(0.0278)\end{array}$ & $\begin{array}{l}0.189^{* * *} \\
(0.0262)\end{array}$ & $\begin{array}{l}0.189^{* * *} \\
(0.0269)\end{array}$ & $\begin{array}{l}-0.00278 \\
(0.0465)\end{array}$ & $\begin{array}{l}-0.00420 \\
(0.0437)\end{array}$ & $\begin{array}{l}-0.000158 \\
(0.0404)\end{array}$ & $\begin{array}{l}-0.00398 \\
(0.0436)\end{array}$ & $\begin{array}{l}0.0780 \\
(0.0398)\end{array}$ & $\begin{array}{l}0.0780 \\
(0.0404)\end{array}$ \\
\hline Sub-Saharan Africa & $\begin{array}{l}0.265^{\star *} \\
(0.0820)\end{array}$ & $\begin{array}{l}0.281^{* * *} \\
(0.0745)\end{array}$ & $\begin{array}{l}0.352^{* * *} \\
(0.0740)\end{array}$ & $\begin{array}{l}0.282^{* *} \\
(0.0799)\end{array}$ & $\begin{array}{l}0.393^{* * *} \\
(0.0504)\end{array}$ & $\begin{array}{l}0.353 \\
(0.221)\end{array}$ & $\begin{array}{l}0.0627 \\
(0.124)\end{array}$ & $\begin{array}{l}0.0761 \\
(0.117)\end{array}$ & $\begin{array}{l}0.110 \\
(0.101)\end{array}$ & $\begin{array}{l}0.0464 \\
(0.113)\end{array}$ & $\begin{array}{l}0.164 \\
(0.0921)\end{array}$ & $\begin{array}{l}0.175 \\
(0.241)\end{array}$ \\
\hline \multicolumn{13}{|l|}{ Firm characteristics } \\
\hline Size dummy: $<5$ & $\begin{array}{l}0.446^{\star * *} \\
(0.0714)\end{array}$ & $\begin{array}{l}0.407^{\star * *} \\
(0.0696)\end{array}$ & & $\begin{array}{l}0.407^{\star * *} \\
(0.0691)\end{array}$ & $\begin{array}{l}0.301^{* * *} \\
(0.0510)\end{array}$ & $\begin{array}{l}0.302^{\star * *} \\
(0.0476)\end{array}$ & $\begin{array}{l}0.240^{\star *} \\
(0.0790)\end{array}$ & $\begin{array}{l}0.205^{\star} \\
(0.0767)\end{array}$ & & $\begin{array}{l}0.209^{* *} \\
(0.0738)\end{array}$ & $\begin{array}{l}0.121 \\
(0.0696)\end{array}$ & $\begin{array}{l}0.121 \\
(0.0634)\end{array}$ \\
\hline Size dummy: 6-20 & $\begin{array}{l}0.336^{\star * *} \\
(0.0545)\end{array}$ & $\begin{array}{l}0.291^{* * *} \\
(0.0525)\end{array}$ & & $\begin{array}{l}0.291^{* * *} \\
(0.0527)\end{array}$ & $\begin{array}{l}0.208^{* * *} \\
(0.0414)\end{array}$ & $\begin{array}{l}0.209^{* \star *} \\
(0.0385)\end{array}$ & $\begin{array}{l}0.194^{* *} \\
(0.0577)\end{array}$ & $\begin{array}{l}0.154^{* *} \\
(0.0547)\end{array}$ & & $\begin{array}{l}0.157^{* *} \\
(0.0527)\end{array}$ & $\begin{array}{l}0.0886 \\
(0.0519)\end{array}$ & $\begin{array}{l}0.0883 \\
(0.0470)\end{array}$ \\
\hline Size dummy: 21-100 & $\begin{array}{l}0.150^{* *} \\
(0.0463)\end{array}$ & $\begin{array}{l}0.124^{*} \\
(0.0457)\end{array}$ & & $\begin{array}{l}0.124^{*} \\
(0.0458)\end{array}$ & $\begin{array}{l}0.0963^{*} \\
(0.0394)\end{array}$ & $\begin{array}{l}0.0967^{*} \\
(0.0382)\end{array}$ & $\begin{array}{l}0.0900 \\
(0.0478)\end{array}$ & $\begin{array}{l}0.0668 \\
(0.0458)\end{array}$ & & $\begin{array}{l}0.0676 \\
(0.0451)\end{array}$ & $\begin{array}{l}0.0446 \\
(0.0439)\end{array}$ & $\begin{array}{l}0.0445 \\
(0.0420)\end{array}$ \\
\hline Foreign ownership & & $\begin{array}{l}-0.246^{* * *} \\
(0.0425)\end{array}$ & $\begin{array}{l}-0.310^{* * *} \\
(0.0501)\end{array}$ & $\begin{array}{l}-0.246^{* * *} \\
(0.0420)\end{array}$ & $\begin{array}{l}-0.161^{* * *} \\
(0.0341)\end{array}$ & $\begin{array}{l}-0.162^{* * *} \\
(0.0323)\end{array}$ & & $\begin{array}{l}-0.224^{* * *} \\
(0.0430)\end{array}$ & $\begin{array}{l}-0.261^{* * *} \\
(0.0493)\end{array}$ & $\begin{array}{l}-0.226^{* * *} \\
(0.0424)\end{array}$ & $\begin{array}{l}-0.157^{* * *} \\
(0.0380)\end{array}$ & $\begin{array}{l}-0.157^{\star * *} \\
(0.0359)\end{array}$ \\
\hline Firm age & & $\begin{array}{l}-0.000667 \\
(0.00111)\end{array}$ & $\begin{array}{l}-0.00196 \\
(0.00126)\end{array}$ & $\begin{array}{l}-0.000656 \\
(0.00138)\end{array}$ & $\begin{array}{l}-0.0000341 \\
(0.000896)\end{array}$ & $\begin{array}{l}-0.0000260 \\
(0.000888)\end{array}$ & & $\begin{array}{l}-0.000289 \\
(0.000954)\end{array}$ & $\begin{array}{l}-0.00103 \\
(0.00104)\end{array}$ & $\begin{array}{l}-0.000759 \\
(0.00134)\end{array}$ & $\begin{array}{l}0.000211 \\
(0.000828)\end{array}$ & $\begin{array}{l}0.000209 \\
(0.000818)\end{array}$ \\
\hline Number of employees & & & $\begin{array}{l}-0.0000880 \\
(0.0000444)\end{array}$ & & & & & & $\begin{array}{l}-0.0000382 \\
(0.0000498)\end{array}$ & & & \\
\hline $\mathrm{SSA}^{\times}$no of employees & & & $\begin{array}{l}-0.000284 \\
(0.000191)\end{array}$ & & & & & & $\begin{array}{l}-0.0000853 \\
(0.000193)\end{array}$ & & & \\
\hline$S S A \times$ firm age & & & & $\begin{array}{l}-0.0000427 \\
(0.00233)\end{array}$ & & & & & & $\begin{array}{l}0.00182 \\
(0.00246)\end{array}$ & & \\
\hline log capital per worker & & & & & $\begin{array}{l}-0.131^{* * *} \\
(0.0216)\end{array}$ & $\begin{array}{l}-0.134^{* * *} \\
(0.0289)\end{array}$ & & & & & $\begin{array}{l}-0.104^{* * *} \\
(0.0197)\end{array}$ & $\begin{array}{l}-0.103^{* *} \\
(0.0278)\end{array}$ \\
\hline $\mathrm{SSA}^{\times} \log$ capital per wk & & & & & & $\begin{array}{l}0.00519 \\
(0.0317)\end{array}$ & & & & & & $\begin{array}{l}-0.00140 \\
(0.0345)\end{array}$ \\
\hline Constant & $\begin{array}{l}-2.799^{* * *} \\
(0.236)\end{array}$ & $\begin{array}{l}-2.652^{* * *} \\
(0.198)\end{array}$ & $\begin{array}{l}-2.500^{\star * *} \\
(0.227)\end{array}$ & $\begin{array}{l}-2.652^{* * *} \\
(0.199)\end{array}$ & $\begin{array}{l}-2.391^{* * *} \\
(0.127)\end{array}$ & $\begin{array}{l}-2.379^{* * *} \\
(0.152)\end{array}$ & $\begin{array}{l}-1.312^{* *} \\
(0.369)\end{array}$ & $\begin{array}{l}-1.239^{\star *} \\
(0.349)\end{array}$ & $\begin{array}{l}-1.159^{* *} \\
(0.336)\end{array}$ & $\begin{array}{l}-1.233^{* *} \\
(0.347)\end{array}$ & $\begin{array}{l}-1.034^{* *} \\
(0.300)\end{array}$ & $\begin{array}{l}-1.037^{* *} \\
(0.317)\end{array}$ \\
\hline $\begin{array}{l}\text { Industry dummies } \\
\text { Observations }\end{array}$ & $\begin{array}{l}\text { Yes } \\
10502\end{array}$ & $\begin{array}{l}\text { Yes } \\
10197\end{array}$ & $\begin{array}{l}\text { Yes } \\
10197\end{array}$ & $\begin{array}{l}\text { Yes } \\
10197\end{array}$ & $\begin{array}{l}\text { Yes } \\
10197\end{array}$ & $\begin{array}{l}\text { Yes } \\
10197\end{array}$ & $\begin{array}{l}\text { Yes } \\
10479\end{array}$ & $\begin{array}{l}\text { Yes } \\
10174\end{array}$ & $\begin{array}{l}\text { Yes } \\
10174\end{array}$ & $\begin{array}{l}\text { Yes } \\
10174\end{array}$ & $\begin{array}{l}\text { Yes } \\
10174\end{array}$ & $\begin{array}{l}\text { Yes } \\
10174\end{array}$ \\
\hline
\end{tabular}

Note: Unit labor cost (sales) are labor cost per worker divided by sales per worker. Unit labor cost (value added) are labor cost per worker divided by total sales less raw material costs per worker. All currency values are in constant 2005 USD. GDP per capita at market exchange rates. Robust standard errors, clustered by region, shown in parentheses: $* p<0.05, * * p<0.01,{ }^{* * *} p<0.001$.

Source: Authors' calculations, based on World Bank Enterprise Surveys data. 


\section{B. Figures}

Figure 1: Range of Labor Cost per Worker and GDP per Capita

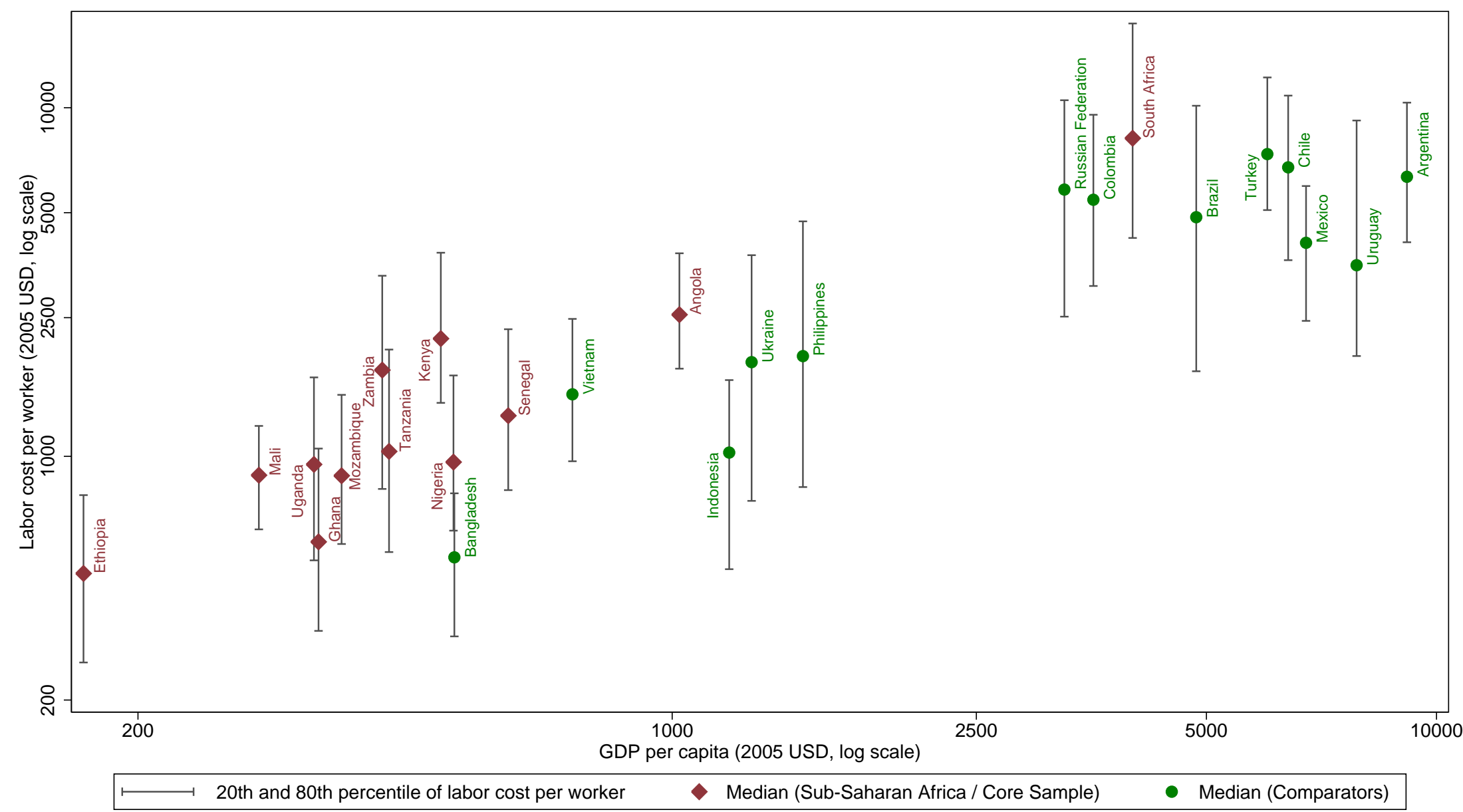

Source: Authors' calculations, based on World Bank Enterprise Surveys data, World Bank World Development Indicators. 
Figure 2: Range of Value Added per Worker and GDP per Capita

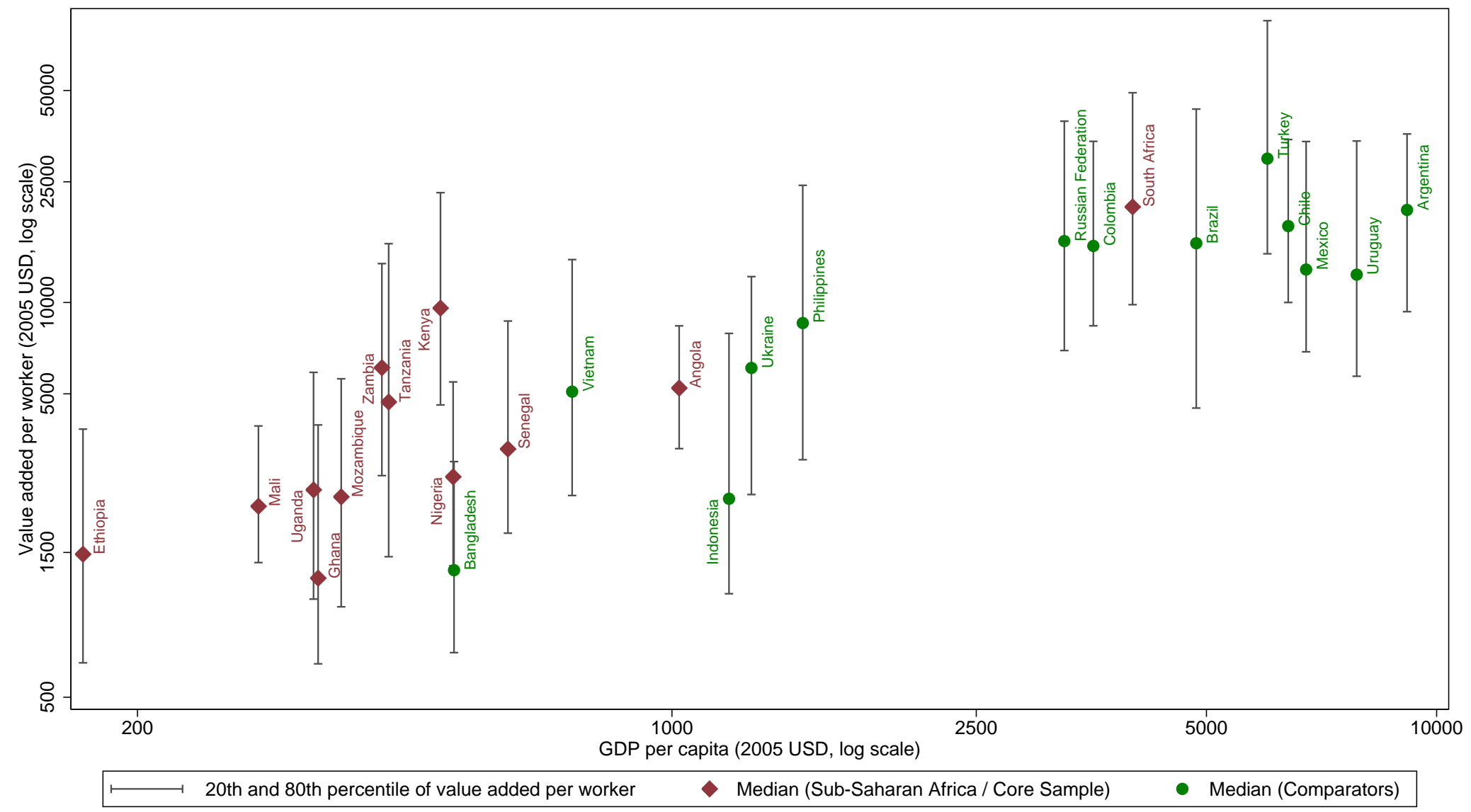

Note: Value added per worker is defined as total sales less raw material costs per worker.

Source: Authors' calculations, based on World Bank Enterprise Surveys data, World Bank World Development Indicators. 
Figure 3: Range of Unit Labor Cost (Based on Sales) and GDP per Capita

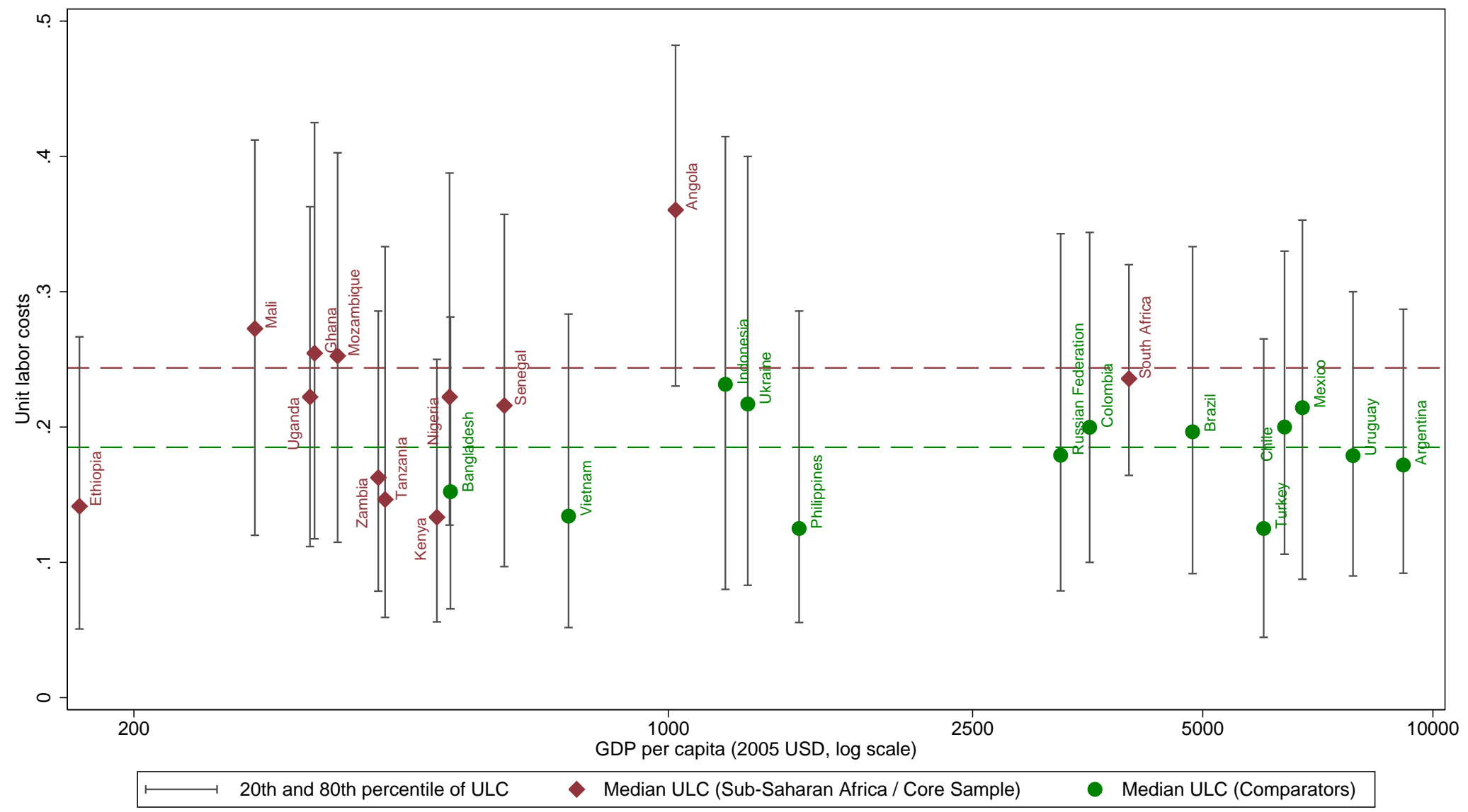

Note: Unit labor cost is defined as labor cost per worker divided by sales per worker.

Source: Authors' calculations, based on World Bank Enterprise Surveys data, World Bank World Development Indicators. 
Figure 4: Adjusted Predictions Based on Mincer-type Earnings Function Models
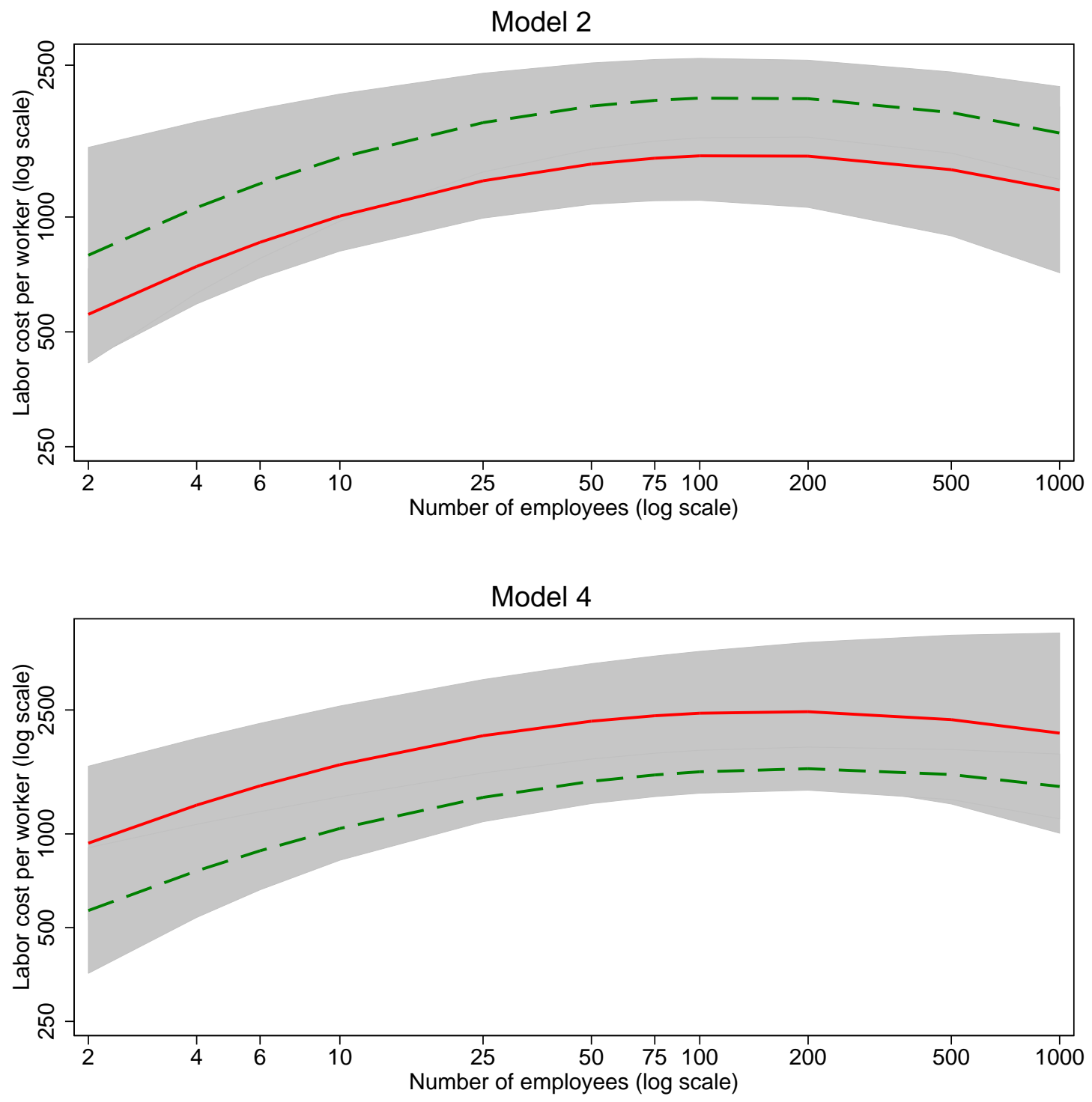

\begin{tabular}{ll}
\hline- & Sub-Saharan Africa: Ghana, Zambia, Mozambique, Senegal \\
- & Comparators: Vietnam, Philippines, Brazil, Indonesia
\end{tabular}

Note: Adjusted predictions, holding all factors and continuous variables at their means. Grey areas show 95 percent confidence intervals. Based on regression results from Table 4. Model 4 controls for GDP per capita.

Source: Authors' calculations, based on World Bank Enterprise Surveys data. 
Figure 5: Adjusted Predictions Based on Mincer-type Earnings Function, Model 4, by Firm Ownership

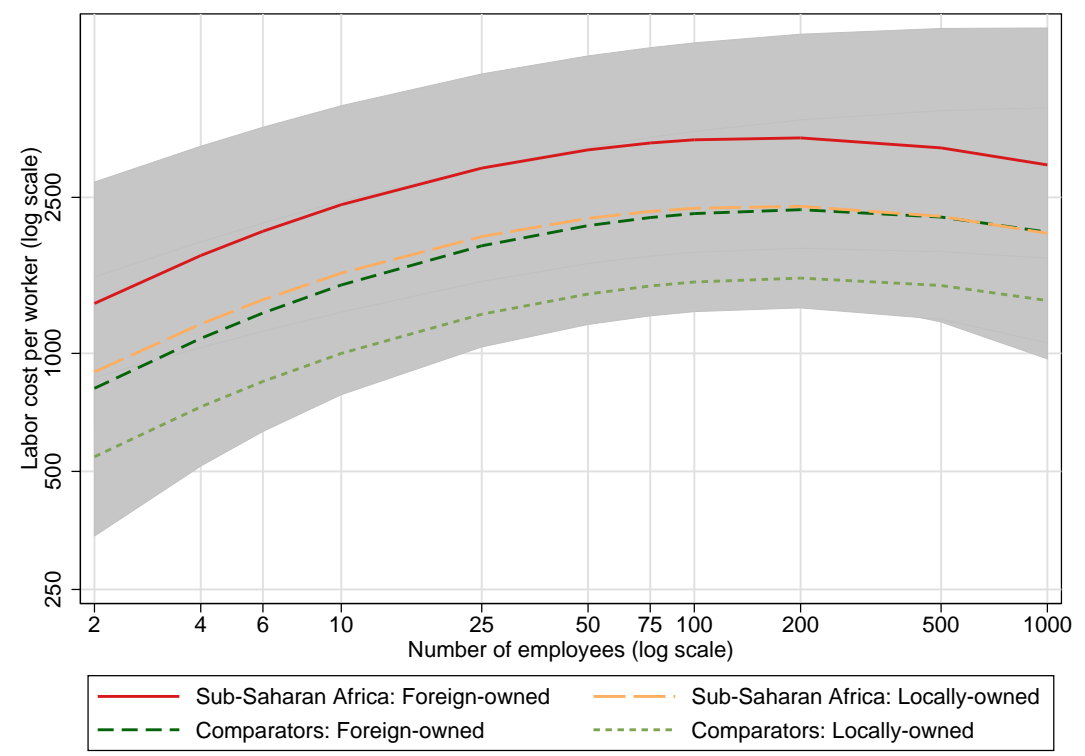

Note: Adjusted predictions, holding all factors and continuous variables at their means. Grey areas show 95 percent confidence intervals. Based on regression results from Table 4, Model 4.

Source: Authors' calculations, based on World Bank Enterprise Surveys data.

Figure 6: Adjusted Predictions based on Value-Added Model 11, by Region

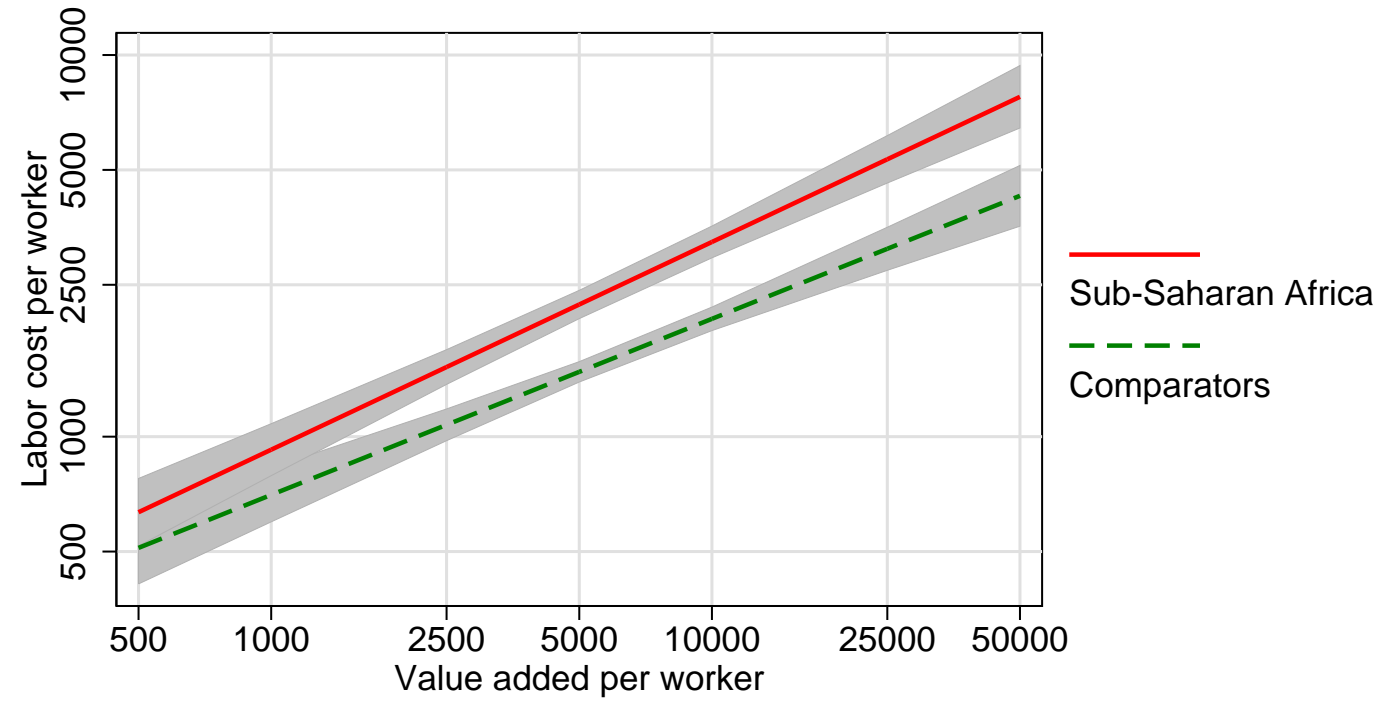

Note: Adjusted predictions, holding all factors and continuous variables at their means. Grey areas show 95 percent confidence intervals. Based on regression results from Table 5, Model 11.

Source: Authors' calculations, based on World Bank Enterprise Surveys data. 
Figure 7: Adjusted Predictions based on Value-Added Model 11, by Region \& Firm Size

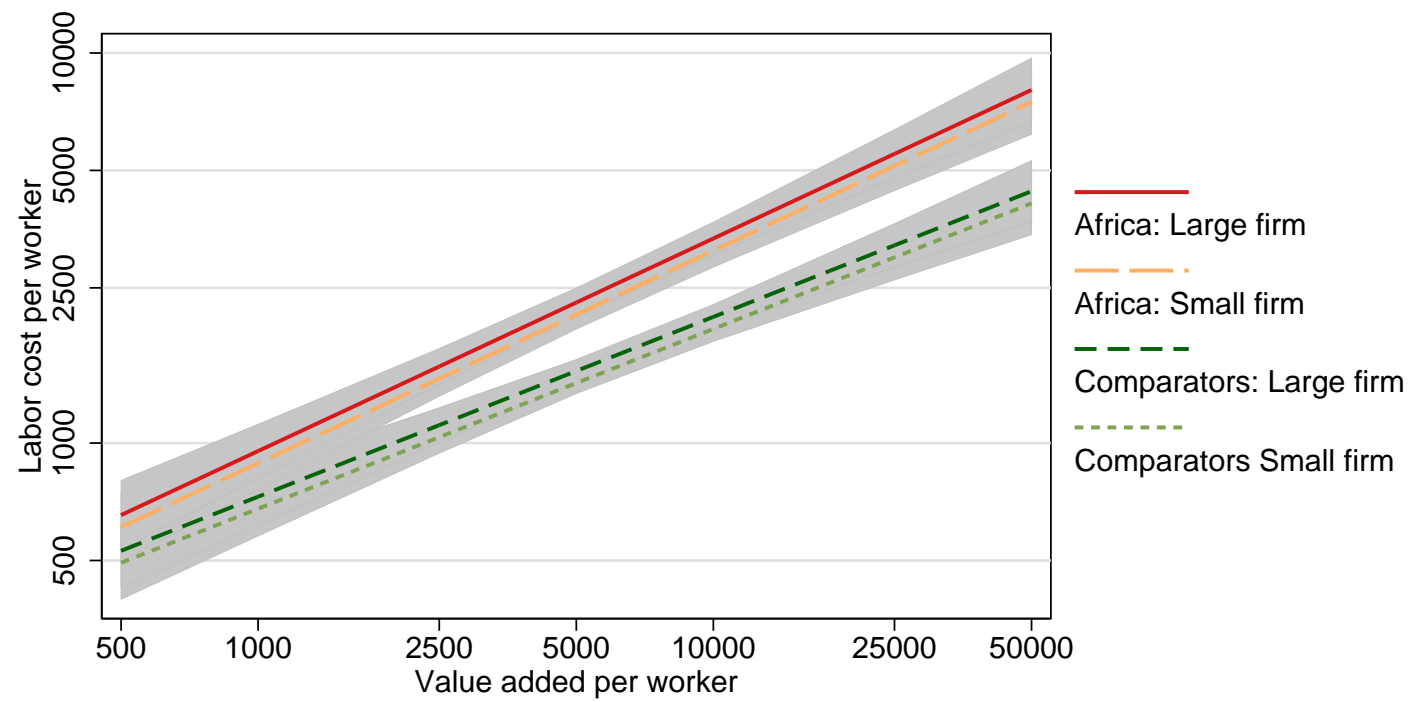

Note: Adjusted predictions, holding all factors and continuous variables at their means. Grey areas show 95 percent confidence intervals. Small firms have 20 or less employees, large firms have more than 20 employees. Based on regression results from Table 5, Model 11.

Source: Authors' calculations, based on World Bank Enterprise Surveys data.

Figure 8: Adjusted Predictions based on Value-Added Model 11, by Region \& Capital Intensity

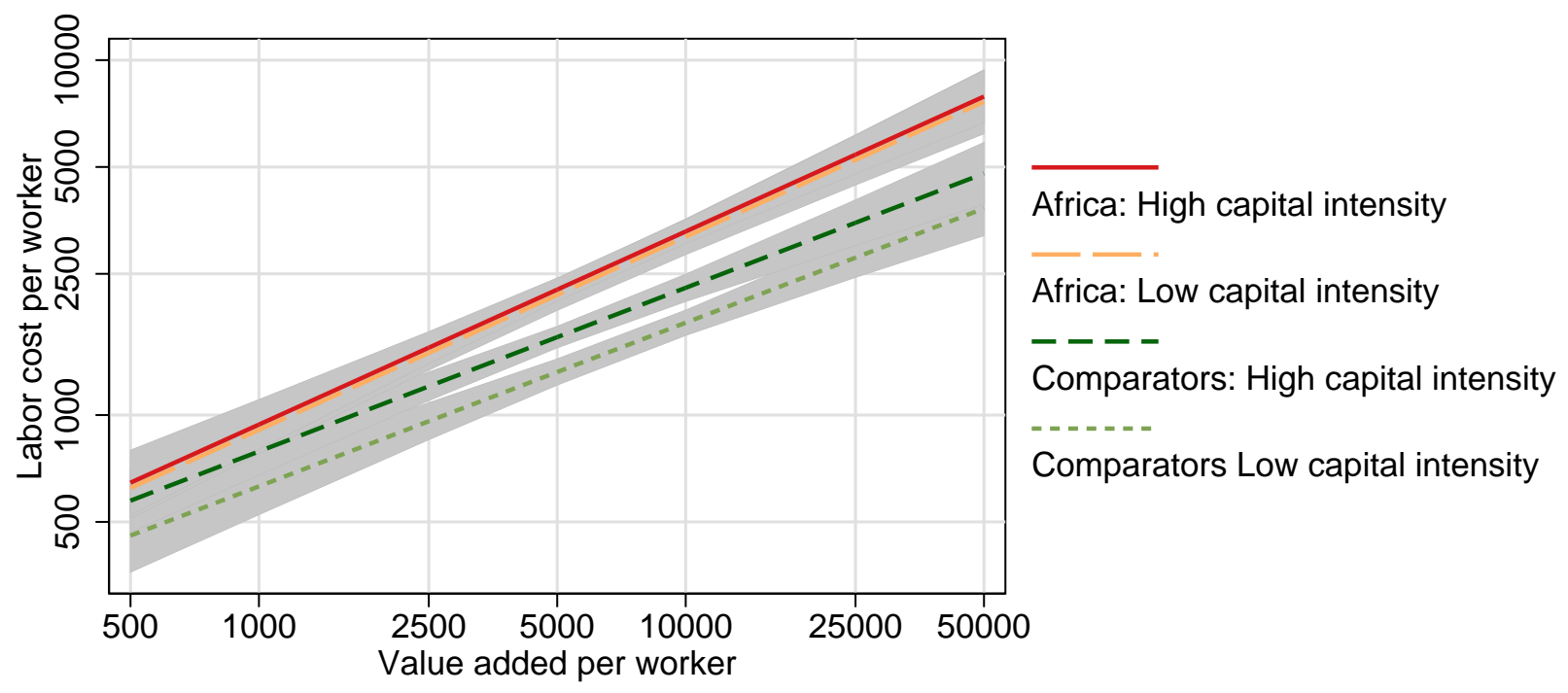

Note: Adjusted predictions, holding all factors and continuous variables at their means. Grey areas show 95 percent confidence intervals. Low (high) capital intensity represents a hypothetical firm with a capital per worker ratio at the 25 th (75th) percentile of the sample-wide distribution. Based on regression results from Table 5, Model 11.

Source: Authors' calculations, based on World Bank Enterprise Surveys data. 
Figure 9: Adjusted Predictions based on Value-Added Model, Food Processing

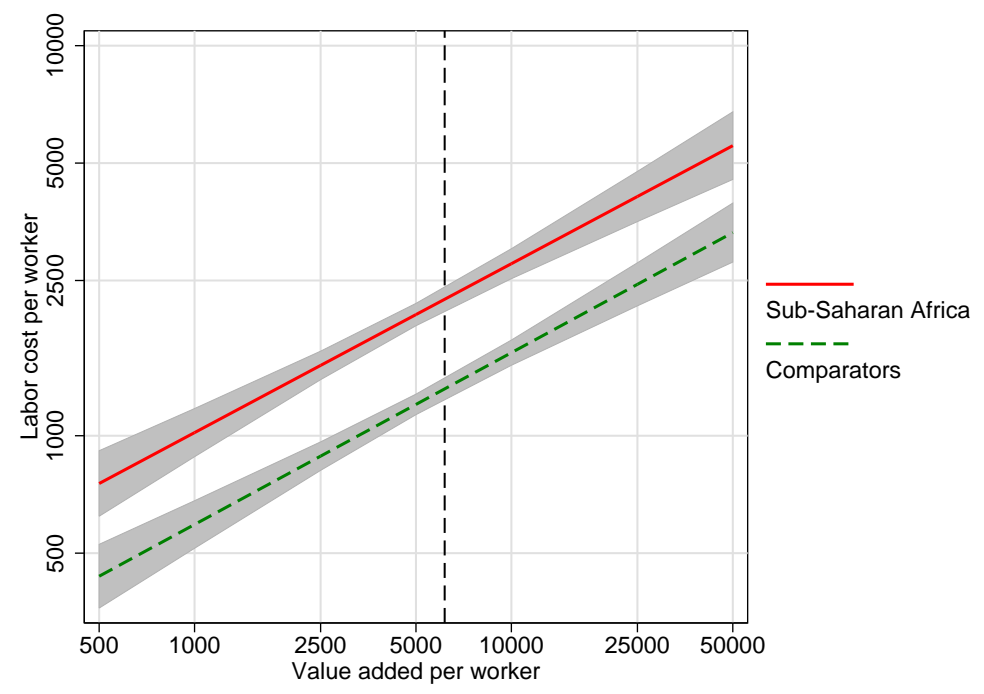

Note: Predicted labor cost per worker for firm with value added of $\$ 6,159$ (industry-specific mean, dashed vertical line): Comparators $\$ 1,319$; Sub-Saharan Africa $\$ 2,238$ (69 percent markup).

Adjusted predictions, holding all factors and continuous variables at their means. Grey areas show 95 percent confidence intervals. Based on regression results from Table 5, Model 11 (food processing; 2,204 observations). Source: Authors' calculations, based on World Bank Enterprise Surveys data.

Figure 10: Adjusted Predictions based on Value-Added Model, Textiles

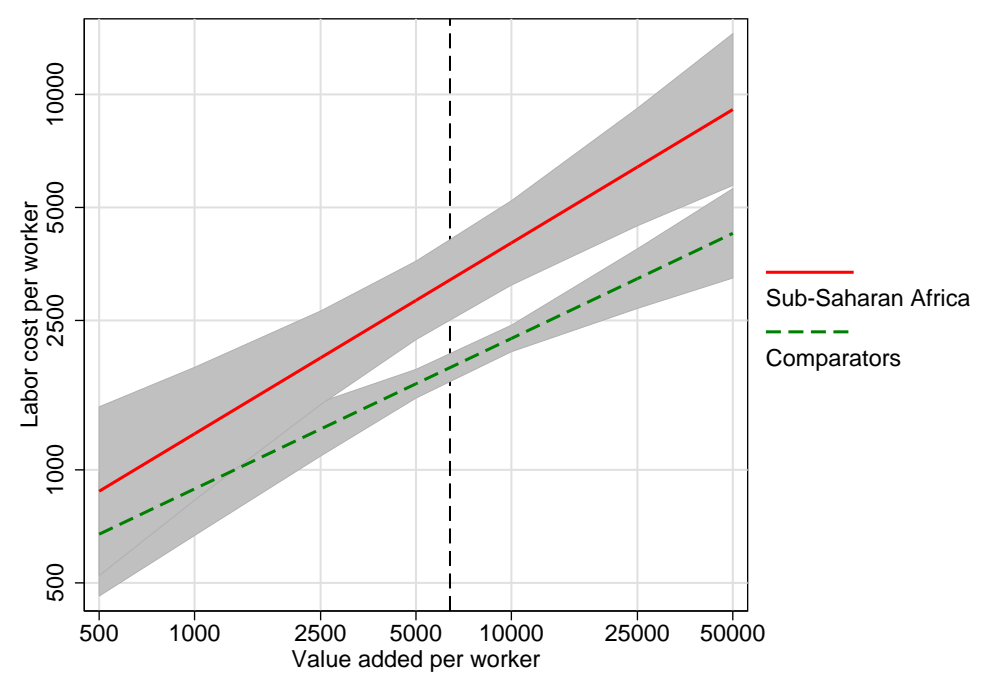

Note: Predicted labor cost per worker for firm with value added of $\$ 6,402$ (industry-specific mean, dashed vertical line): Comparators $\$ 1,872$; Sub-Saharan Africa $\$ 3,206$ (71 percent markup).

Adjusted predictions, holding all factors and continuous variables at their means. Grey areas show 95 percent confidence intervals. Based on regression results from Table 5, Model 11 (textiles; 935 observations). Source: Authors' calculations, based on World Bank Enterprise Surveys data. 
Figure 11: Adjusted Predictions based on Value-Added Model, Garments

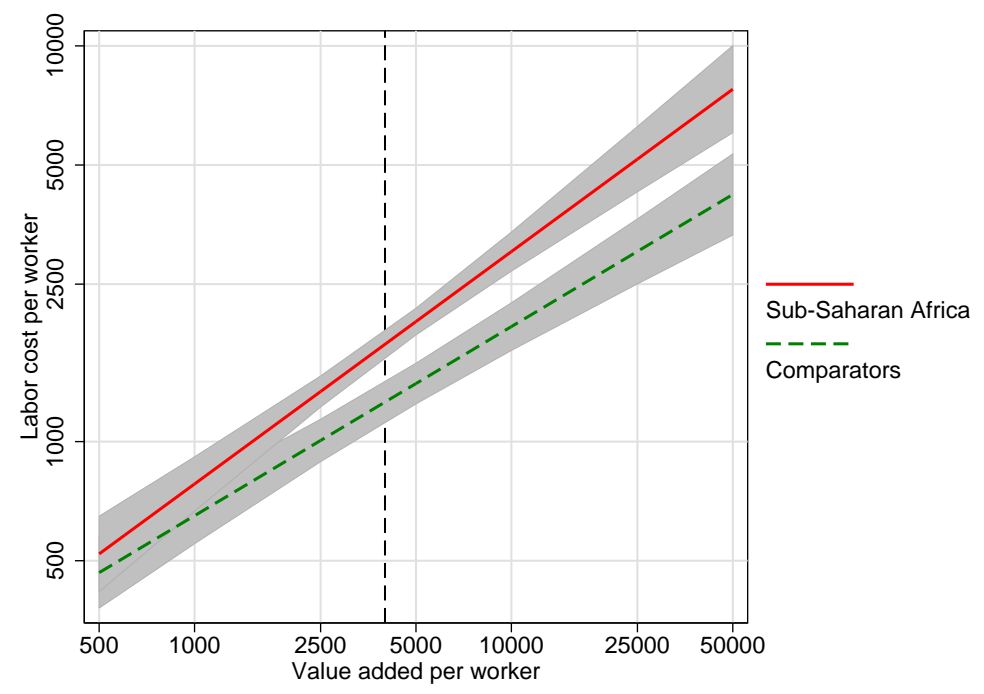

Note: Predicted labor cost per worker for firm with value added of $\$ 3,991$ (industry-specific mean, dashed vertical line): Comparators $\$ 1,259$; Sub-Saharan Africa $\$ 1,762$ (40 percent markup).

Adjusted predictions, holding all factors and continuous variables at their means. Grey areas show 95 percent confidence intervals. Based on regression results from Table 5, Model 11 (garments; 1,769 observations). Source: Authors' calculations, based on World Bank Enterprise Surveys data.

Figure 12: Adjusted Predictions based on Value-Added Model, Chemicals

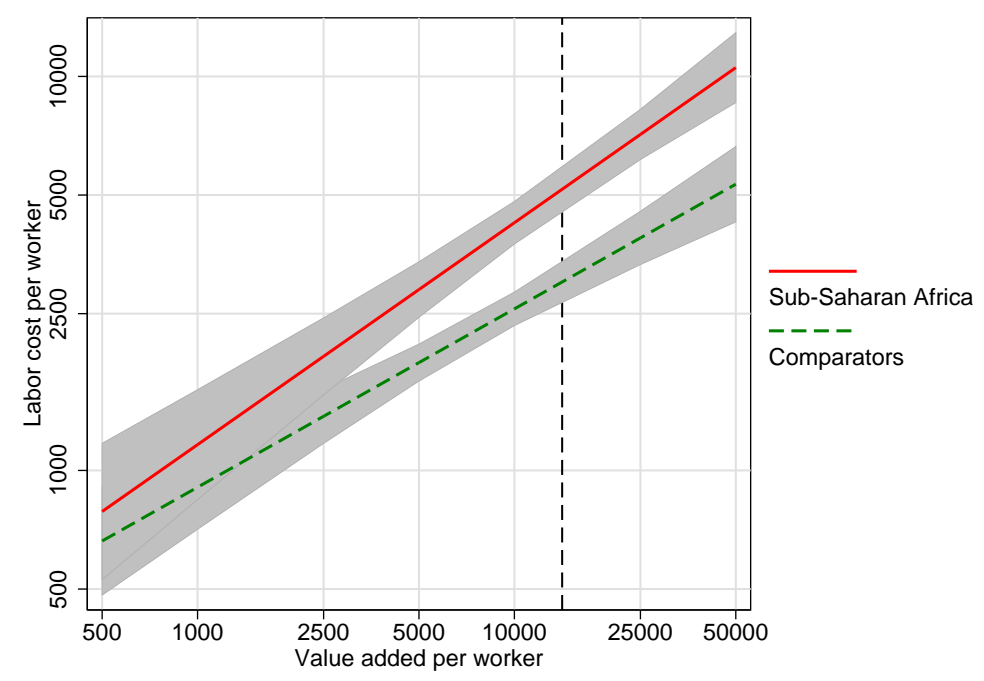

Note: Predicted labor cost per worker for firm with value added of $\$ 14,153$ (industry-specific mean, dashed vertical line): Comparators $\$ 3,008$; Sub-Saharan Africa $\$ 5171$ (72 percent markup).

Adjusted predictions, holding all factors and continuous variables at their means. Grey areas show 95 percent confidence intervals. Based on regression results from Table 5, Model 11 (chemicals; 904 observations). Source: Authors' calculations, based on World Bank Enterprise Surveys data. 
Figure 13: Adjusted Predictions based on Value-Added Model, Non-Metallic \& Base Metals

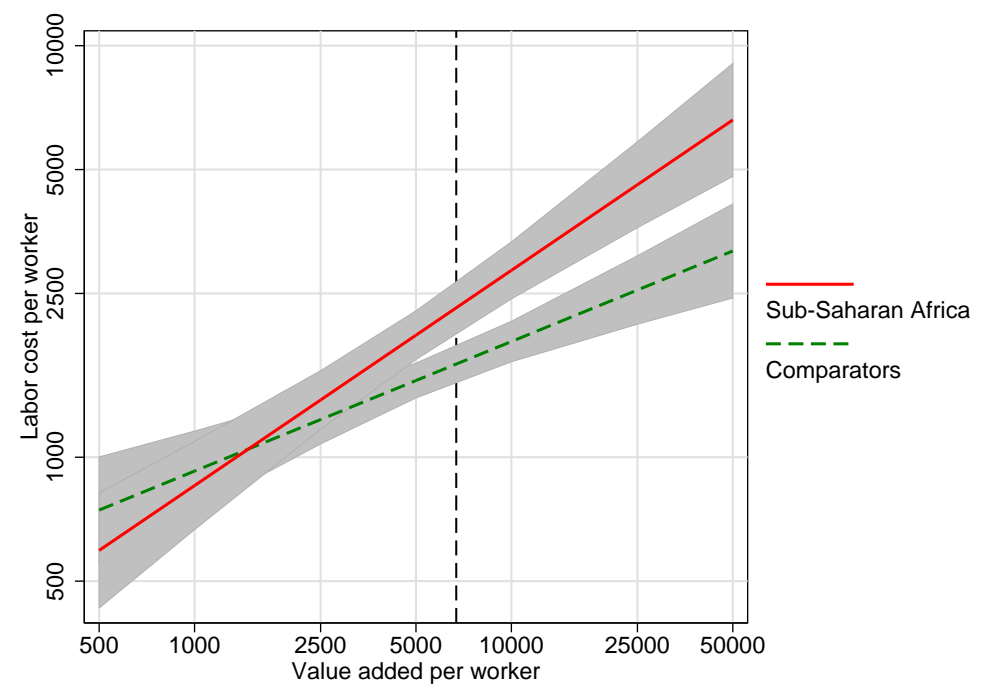

Note: Predicted labor cost per worker for firm with value added of $\$ 6,699$ (industry-specific mean, dashed vertical line): Comparators $\$ 1,684$; Sub-Saharan Africa $\$ 2,307$ (37 percent markup).

Adjusted predictions, holding all factors and continuous variables at their means. Grey areas show 95 percent confidence intervals. Based on regression results from Table 5, Model 11 (non-metallic and base metals; 644 observations).

Source: Authors' calculations, based on World Bank Enterprise Surveys data.

Figure 14: Adjusted Predictions based on Value-Added Model, Fabricated Metals

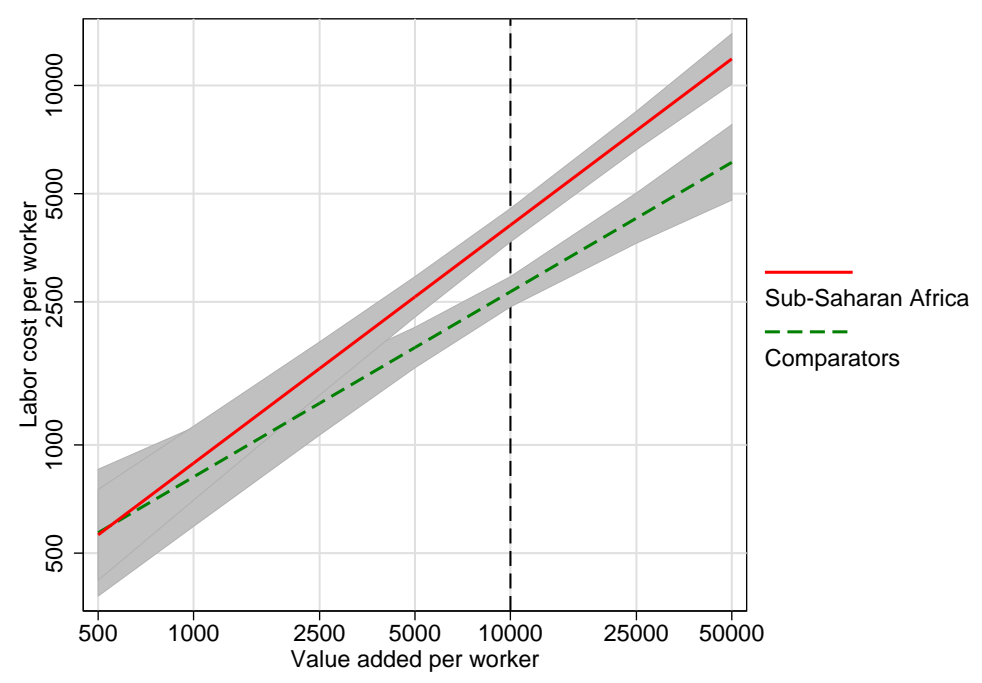

Note: Predicted labor cost per worker for firm with value added of $\$ 10,007$ (industry-specific mean, dashed vertical line): Comparators $\$ 2,668$; Sub-Saharan Africa $\$ 4,087$ (53 percent markup).

Adjusted predictions, holding all factors and continuous variables at their means. Grey areas show 95 percent confidence intervals. Based on regression results from Table 5, Model 11 (fabricated metals and machinery; 1,402 observations).

Source: Authors' calculations, based on World Bank Enterprise Surveys data. 
Figure 15: Adjusted Predictions based on Unit Labor Cost Model 6, by Capital Intesity

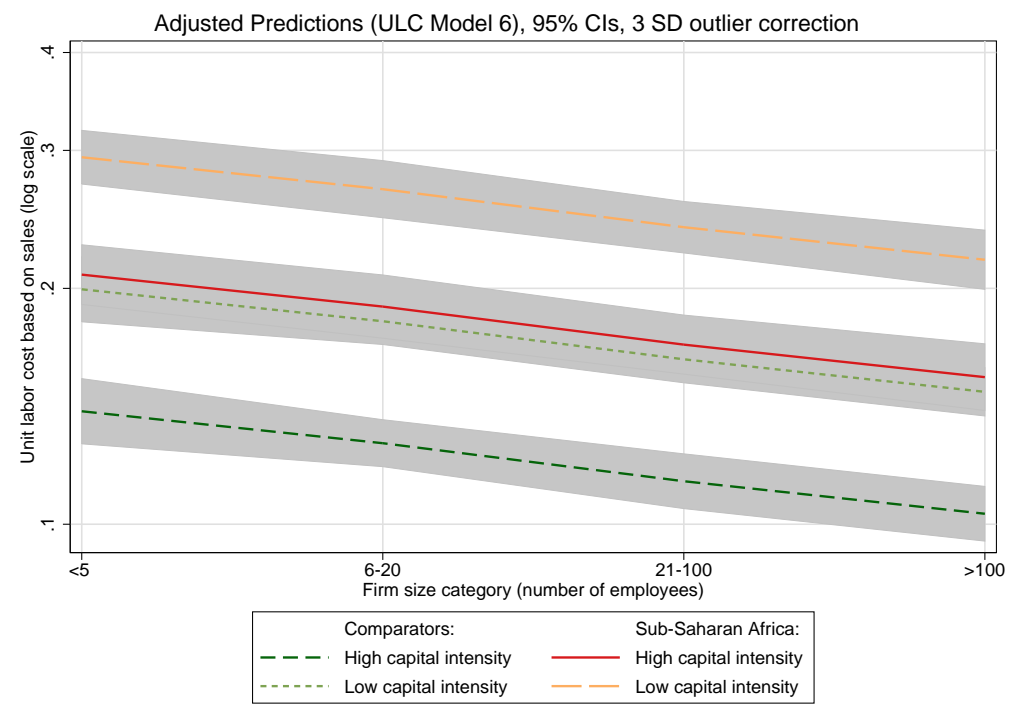

Note: Adjusted predictions for unit labor cost (based on sales), holding all factors and continuous variables at their means. Grey areas show 95 percent confidence intervals. Low (high) capital intensity represents a hypothetical firm with a capital per worker ratio at the 25 th $(75 \mathrm{th})$ percentile of the sample-wide distribution. Based on regression results from Table 6 , Model 6.

Source: Authors' calculations, based on World Bank Enterprise Surveys data. 
Figure 16: Balassa-Samuelson Relationship: Price Level and GDP per Capita (5-year Average 2005 to 2009)

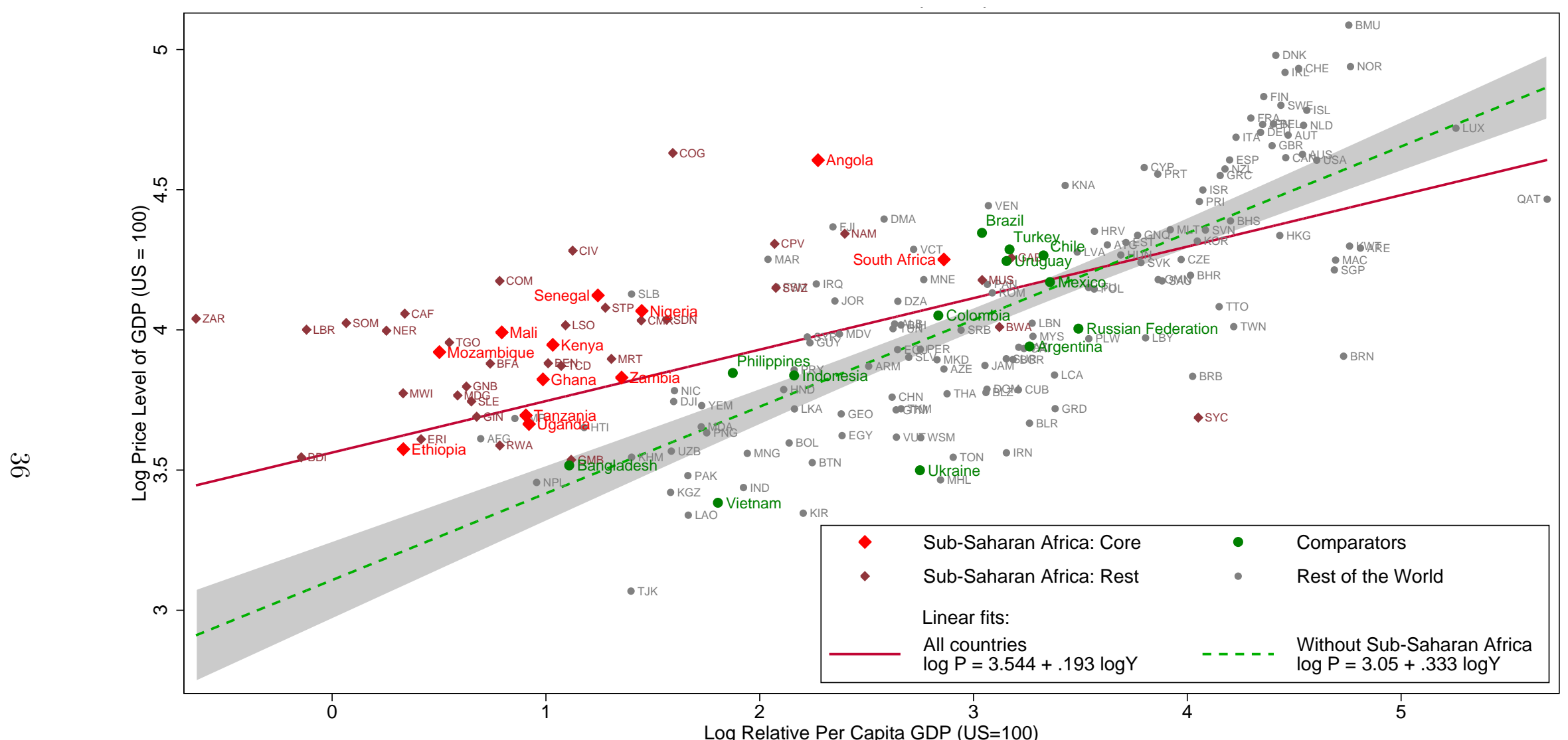

Note: Specification replicates Rogoff (1996, p. 660), 188 observations (Zimbabwe excluded). Grey area shows 95 percent confidence interval. Source: Authors' calculations, based on Penn World Tables 7.0 (May 2011). 
Figure 17: Balassa-Samuelson Relationship: Residuals by Country

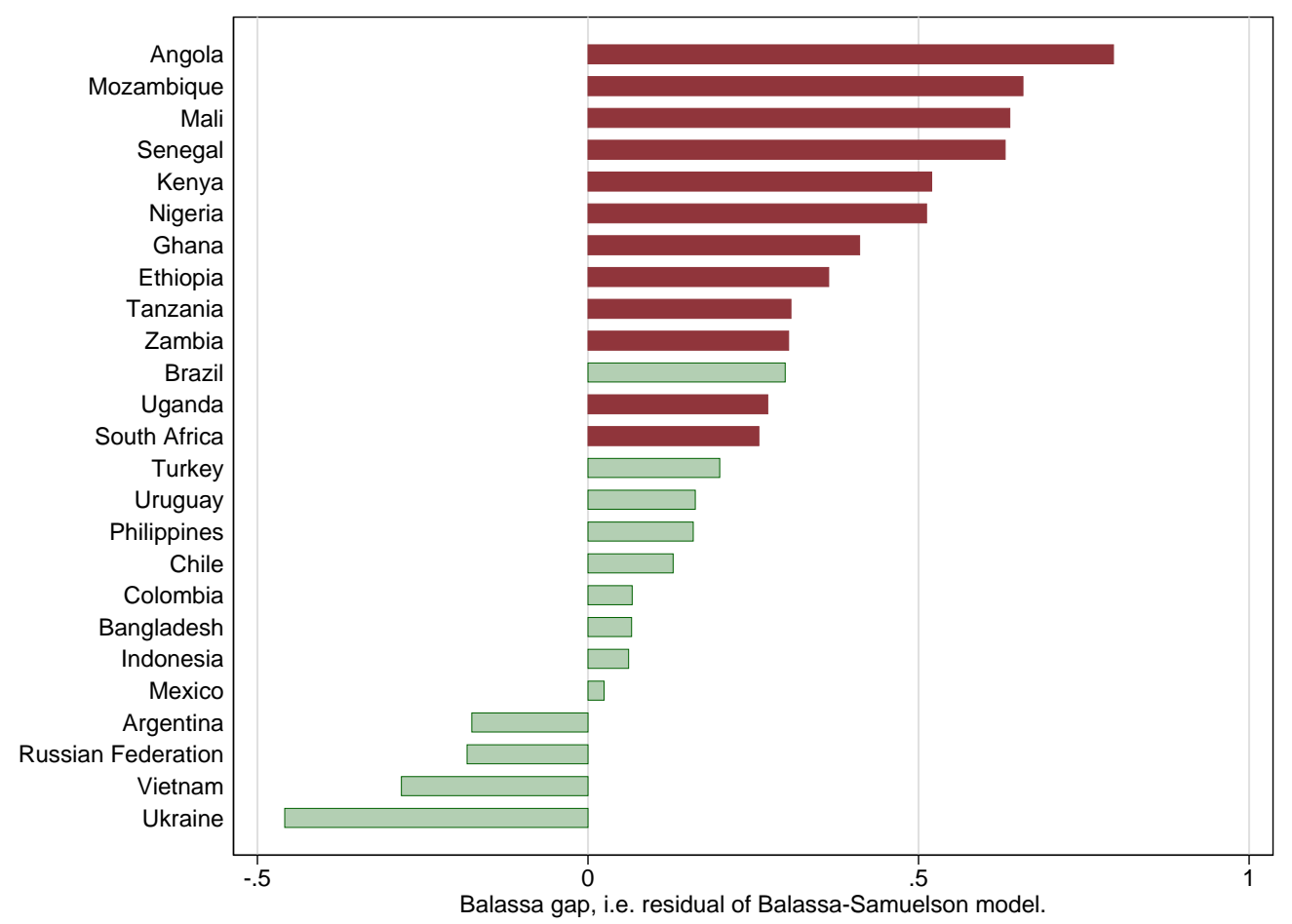

Note: Deviation from linear fit in Figure 16. Specification replicates Rogoff (1996, p. 660).

Source: Authors' calculations, based on Penn World Tables 7.0 (May 2011). 